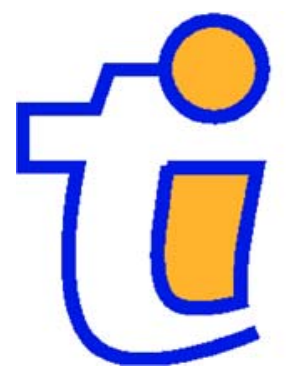

TI 2010-010/3

Tinbergen Institute Discussion Paper

Income Taxation in an Empirical

Collective Household Labour Supply

Model with Discrete Hours

Hans G. Bloemen

VU University Amsterdam, and Tinbergen Institute. 


\section{Tinbergen Institute}

The Tinbergen Institute is the institute for economic research of the Erasmus Universiteit Rotterdam, Universiteit van Amsterdam, and Vrije Universiteit Amsterdam.

Tinbergen Institute Amsterdam

Roetersstraat 31

1018 WB Amsterdam

The Netherlands

Tel.: +31(0)205513500

Fax: $+31(0) 205513555$

Tinbergen Institute Rotterdam

Burg. Oudlaan 50

3062 PA Rotterdam

The Netherlands

Tel.: + $31(0) 104088900$

Fax: $+31(0) 104089031$

Most TI discussion papers can be downloaded at http://www.tinbergen.nl. 


\title{
INCOME TAXATION IN AN EMPIRICAL COLLECTIVE HOUSEHOLD LABOUR SUPPLY MODEL WITH DISCRETE HOURS
}

\author{
by
}

\author{
Hans G. Bloemen ${ }^{1} 2$ \\ Department of Economics \\ Free University Amsterdam \\ De Boelelaan 1105 \\ $1081 \mathrm{HV}$ Amsterdam \\ The Netherlands
}

January 2010

Keywords: Labour supply, Household behaviour, Collective model, Taxation JEL code: J22

\begin{abstract}
Most empirical studies on the impact of labour income taxation on the labour supply behaviour of households use a unitary modelling approach. In this paper we empirically analyze income taxation and the choice of working hours by combining the collective approach for household behaviour and the discrete hours choice framework with fixed costs of work. We identify the sharing rule parameters with data on working hours of both the husband and the wife within a couple. Parameter estimates are used to evaluate various model outcomes, like the wage elasticities of labour supply and the impacts of wage changes on the income sharing between husband and wife. We also simulate the consequences of a policy change in the tax system. We find that the collective model has different empirical outcomes of income sharing than a restricted model that imposes pooling of men's earnings and the household's non-labour income in the female's budget constraint. These differences in outcomes have consequences for the evaluation of a policy change in the tax system.
\end{abstract}

\footnotetext{
${ }^{1}$ We are greatly indebted to Statistics Netherlands for providing the data.

${ }^{2}$ email: hbloemen@feweb.vu.nl, phone: +31 20 5986037, fax: +31 205986005
} 


\section{Introduction}

The empirical literature on labour supply has devoted much attention to the evaluation of the impact of the income tax system on the choice of working hours and the participation decision. ${ }^{3}$ The focus of the analysis has been increasingly directed towards the joint labour supply decision of couples. ${ }^{4}$ Studies known in the literature almost invariably use the unitary model of household labour supply for this analysis. The unitary approach assumes the existence of a household utility function, and does not specify the preferences of the individual household members. Therefore, the intrahousehold allocation process is ignored. As an empirical implication for the analysis of income taxes, the unitary model provides no conclusions about the process of income sharing between household members as income pooling is imposed. Labour supply studies that have tested for the restrictions of the unitary model on the labour supply of household members, like for instance the pooling restriction, almost invariably reject the unitary restrictions. ${ }^{5}$

McElroy and Horney (1981) formulated a household decision model that allows for individual preferences of household members, and specifies a Nash bargaining process between husband and wife. The approach by Apps and Rees (1988) only needs the assumption of efficiency, whereas the specification of an explicit bargaining rule is not required. Chiappori $(1988,1992)$ specifies a collective model of household labour supply. The collective model explicitly specifies the preferences of the individual household members, and assumes Pareto efficient bargaining between household members. Chiappori (1988, 1992) showed that under certain conditions, like egoistic (or caring) preferences and the absence of a public good in the household, a sharing rule can be identified up to an additive constant. The sharing rule specifies the allocation of income between household members. The underlying individual preference parameters can be identified.

The empirical application of the collective model is less straightforward than the unitary model, which explains why studies on household labour supply and taxes have

\footnotetext{
${ }^{3}$ See e.g. Blundell and MaCurdy (1999) for an overview.

${ }^{4}$ See e.g. Hausman and Ruud (1984), and Van Soest (1995), Hoynes (1996), Keane and Moffit (1998), and Blundell et al. (1999).

${ }^{5}$ In these studies the tax system is not incorporated explicitly. See e.g. Fortin and Lacroix (1997) for an extensive test of the unitary model.
} 
concentrated on the unitary model, as indicated by Beninger and Laisney (2002). In the collective model it is less straightforward to incorporate the participation decision and taxation. Recently, Blundell et al. (2007) and Donni (2003) extended the identification result of the sharing rule to include the case of nonparticipation by one of the partners. Bloemen (2009) specifies an empirical model of collective household labour supply which allows for nonparticipation.

Donni (2003) derives conditions for the implementation of a nonlinear but convex budget constraint in a collective model. In particular, he shows how the parameters of the sharing rule can be recovered from the labour supply functions that are based on virtual wage rates and virtual nonlabour income. His approach is based on the availability of an explicit expression of the labour supply function (conditional on the tax bracket) and therefore may be interpreted as a collective version of the Hausman and Ruud (1984) approach. Bargain and Moreau (2003) simulate a collective model with taxes and show the implications of using the collective approach various model outcomes. Beninger and Laisney (2002) simulate data from a specification of the collective model and show how changes in the tax system affect model outcomes. They also estimate a discrete hours choice model, similar to Van Soest (1995), with simulated collective data, to see whether the unitary model generates results that are comparable to the collective model from which the data were generated. The unitary model generates substantially different results than the collective model. ${ }^{6}$ Vermeulen (2006) used the discrete hours choice model to empirically implement taxes in a collective type of model. His focus is on couples with husbands in full-time employment. Vermeulen et al. (2006) suggest a calibration approach for modelling collective labour supply with income taxes. Their identification strategy, though, is based on comparing married and single women.

In this study we specify an implementable empirical model of household labour supply with taxes that can be estimated with labour supply data for both husband and wife, is based on individual preferences, and does not a priori impose income pooling, such

\footnotetext{
${ }^{6}$ It should be noted that there may be several causes for the differences between the outcomes, like the use of different utility functions, the use of a discrete choice framework, as well as the specification with the logistic errors. For instance, Beninger and Laisney (2002) find that the model underestimates the probability of nonparticipation, which was also found in the original discrete hours model, even when it is extended with fixed cost of work.
} 
that it can be used for evaluating the household's income sharing process. We aim to identify sharing rule parameters and preferences by using data of husband and wife within couples, rather than by relying on equality of preferences of single and married females ${ }^{7}$ since the restrictions of the collective model set in the original model (Chiappori 1988, 1992) actually are restrictions between the husband's and wife's labour supply. For reasons of flexibility and implementability, we use a discrete hours choice approach. Van Soest (1995) used the discrete model in context of a unitary household labour supply model. The flexible utility specification in this approach makes the model less suitable for welfare comparisons, but the model provides a fit between observable working hours categories and probabilities of finding a worker in any of these categories, which makes the model suitable for analyzing the labour supply outcomes of wage changes. Moreover, the sharing rule describes the assignment of income to the partners within a household, so the model can be used for analyzing the income sharing process.

For reasons of comparison, we estimate different model specifications. As a reference case, we specify a restricted sharing rule that pools the earnings of the husband and the household's non-labour income (as was also done in many empirical studies on female labour supply). The implicit assumption in this specification is that male and female wage rates only enter the decision problem as part of the budget set, and there is no additional influence, as, for instance, bargaining effects. The alternative is a more 'flexible' sharing rule that allows for additional effects of the wage rates and non-labour income on the sharing of income between partners. We also estimate model specifications with and without fixed costs of work. Although the more restricted specifications are nested in the more flexible specifications, we do not think that a statistical test as the likelihood ratio test is the appropriate way to select a preferred model specification. A more flexible specification brings the discrete hours distribution implied by the model easily closer to the empirical distribution function of working hours, and there is a risk of overparametrizing the model. What matters is whether the more flexible specifications really imply different behavioural outcomes. We will evaluate the model on basis of

\footnotetext{
7 The fact that some persons are single and others part of a couple may be related to differences in preferences for the formation of couples (see Manser and Brown, 1980).
} 
elasticities of labour supply, the implications for income sharing, and the simulation of a policy change in the tax system. We use a dataset on childless couples from the Dutch Socio Economic Panel (SEP) for the years 1990-2001.

The results show that the model variants with a more 'flexible' sharing rule have quite different outcomes for the allocation of income between household members, even if differences in wage elasticities of labour supply are not that outspoken.

The organization of the paper is as follows. In section 2 we formulate the collective version of the discrete hours choice model. In section 3 we present the econometric specification of our model. We specify the utility function of husband and wife, the error structure, the sharing rule, and the wage distribution. In section 4 we briefly describe the Dutch income tax system. Section 5 provides descriptive statistics of the data. Section 6 contains the results of estimation and simulation results with tax reforms are presented. Section 7 concludes.

\section{The model}

\subsection{The collective framework}

In this section we formulate the collective discrete choice model for working hours. By formulating a discrete choice model we follow the literature on labour supply and taxes in which the specification of discrete choice models for working hours is common practice nowadays. The ease of implementation of the discrete choice model to incorporate complex tax systems is the main reason for the fact that this model has been applied so widely.

Throughout we will consider a two-member household consisting of husband and wife. The consumption level and the working hours are denoted by $\left(C_{m}, h_{m}\right)$ for the husband and $\left(C_{f}, h_{f}\right)$ for the wife. Utility of each household member is defined over consumption and working hours, and is denoted by $U_{j}\left(C_{j}, h_{j}\right), j=m, f$. We assume that preferences are egoistic, and that there are no public goods in the household. ${ }^{8}$ We

\footnotetext{
${ }^{8}$ Recently, Chiappori et al. (2005) relaxed the assumption of the absence of public goods. However, identification of the model parameters requires information of the households' expenditures on the public good.
} 
assume that individuals allocate their total time across leisure and paid work. Thus, we do not consider time that is spent on household production. ${ }^{9}$ The gross hourly wage rates of husband and wife, and the household's nonlabour income are denoted by $w_{m}, w_{f}$, and $y$ respectively. Individuals may choose their working hours out of the set $S \equiv\left\{h^{0}, h^{1}, \ldots, h^{H}\right\},^{10}$ (with $h^{0}=0, H \geq 1, h^{j}>h^{j-1}, j=1, \ldots, H$ ). We assume that the tax system is known and that the after tax income is a function of the working hours and the gross hourly wage rates of husband and wife, and of the household's non-labour income. Therefore, we denote the after tax income of the household as $g\left(h_{m}, h_{f}, w_{m}, w_{f}, y\right)$.

We assume that for each combination of $\left(h_{m}, h_{f}, w_{m}, w_{f}, y\right)$ there exist virtual wage rates $\omega_{j}=\omega_{j}\left(h_{m}, h_{f}, w_{m}, w_{f}, y\right), j=m, f$, and a virtual nonlabour income $\mu=$ $\mu\left(h_{m}, h_{f}, w_{m}, w_{f}, y\right)$ such that $g\left(h_{m}, h_{f}, w_{m}, w_{f}, y\right)=\omega_{m} h_{m}+\omega_{f} h_{f}+\mu$.

Let $\bar{u}_{m}\left(w_{m}, w_{f}, y\right)$ denote the utility level that is at least available to the husband. This utility level can be interpreted as the outcome of some bargaining process that leads to Pareto efficient allocations. Note that we assume here that the outcome of the bargaining process depends on gross wage rates and nonlabour income. More general specifications are possible. Now we may write the choice problem of the household members according to the collective model as follows: ${ }^{11}$

$$
\begin{gathered}
\max _{h_{m} \in S, h_{f} \in S, C_{m}, C_{f}} U_{f}\left(C_{f}, h_{f}\right) \\
U_{m}\left(C_{m}, h_{m}\right) \geq \bar{u}_{m}\left(w_{m}, w_{f}, y\right) \\
C_{m}+C_{f}=g\left(h_{m}, h_{f}, w_{m}, w_{f}, y\right) \\
S=\left\{h^{0}, \ldots, h^{H}\right\}
\end{gathered}
$$

First, note how the choice of working hours by one partner affects the choice of the other. If the husband decides to choose a higher level of working hours, the total household

\footnotetext{
${ }^{9}$ Chiappori (1997) incorporates household production in the collective labour supply model. Unfortunately, time spent on household production by separate household members is not observed in our data.

${ }^{10}$ In section 4 , in which we describe the data, we will be more specific about the hours values in the choice set.

11 The total time endowment was normalized to 1 . There are alternative representations of the same maximization problem. By writing down the Lagrangian we may obtain the 'household welfare function' which is additive in the utility levels of both husband and wife.
} 
budget changes and consequently the choice of working hours by the wife may be affected. Suppose that the husband's net labour income increases as the result of the increase in his working hours. Then the impact on the working hours of the wife depends on the allocation of this additional income to male and female consumption. If part of the additional income is transferred to the wife and if the wife's leisure is a normal good, she may reduce her working hours. If, however, the additional income is spent entirely on the consumption of the husband, or if the consumption of the wife will be reduced, the wife's working hours may stay the same or increase. Consequently, the interaction of the working hours of husband and wife depends on the way husband and wife share the total household income, which depends both on their relative bargaining power and on their preferences. In the unitary model, the additional income raised by the increase in working hours would be pooled and added to the household income.

\subsection{Discrete choice, Pareto efficiency and double indifference}

The discrete choice framework may impose additional restrictions on the household's income sharing rule. Blundell et al. (2007) formulate a collective model of household labour supply in which the wife can choose from a continuous range of working hours, but the husband's choice is restricted to choosing to work 40 hours a week or not to work at all, and show that Pareto efficiency of the underlying decision problem requires the 'double indifference' condition. This condition states that if the husband is indifferent between working (40 hours a week) or not working, the wife is also indifferent: the wife's utility level is not affected if the husband's working hours would jump from 40 hours a week to nonparticipation or back if the husband himself is indifferent between these two hours levels. If the wife's utility level were affected, then there would be scope for a Pareto improvement, which is in contradiction with the Pareto efficiency of the household allocation problem. If the husband's working hours change from one level to another, his labour income changes as well. If the husband is indifferent between the two levels of working hours, the change in consumption generated by the change in income exactly offsets the change in utility that is due to the change in working hours. If part of the income change were transferred to the wife, her utility would rise and we would have a 
Pareto improvement which implies that we are not in a Pareto efficient situation. The implication is that at the reservation wage, the additional income raised by the husband by an increase in working hours should be assigned entirely to the husband. Note that this relationship only holds for reservation wage rates, at which the husband is indifferent between the different levels of working hours. At other wages levels, this condition need (and will) not hold, but the condition places restrictions on the relation between the preferences and the income sharing rule. If the choice set of working hours is discrete for a variety of hours levels and different hours levels imply different income levels, the double indifference condition should be satisfied for any pair of choices of working hours of husband and wife. However, if we consider the discrete choice set as an approximation for the continuous hours choice, discrete 'jumps' in income due to 'jumps' in working hours get smaller and smaller the more refined is the discretization of the hours choice set. But if there are discontinuities in the budget constraint, due to the properties of the tax and social security system, then the imposition of double indifference becomes more fundamental.

\subsection{The sharing rule representation}

In this section we formulate the sharing rule representation of the decision problem (1). The discrete choice nature of the decision problem also has implications for the sharing rule. If the husband's working hours are equal to $h_{m} \in S$, then the husband's consumption level is implicitly defined by

$$
u_{m}\left(C_{m}, h_{m}\right)=\bar{u}_{m}\left(w_{m}, w_{f}, y\right)
$$

If $V_{m}\left(., h_{m}\right)$ is the inverse of the mapping $u_{m}\left(., h_{m}\right),{ }^{12}$ we may write

$$
C_{m}=V_{m}\left(\bar{u}_{m}\left(w_{m}, w_{f}, y\right), h_{m}\right)=\psi\left(w_{m}, w_{f}, h_{m}, y\right)
$$

Equation (3) shows that the consumption of the husband depends on the gross hourly wage rates $w_{m}$ and $w_{f}$ of husband and wife, on the household's nonlabour income $y$, and, due to the discrete choice nature of our decision problem, it also depends explicitly on the working hours $h_{m}$.

\footnotetext{
${ }^{12}$ Conform Blundell et al. (2007).
} 
To express consumption in terms of virtual wage rates and virtual nonlabour income, we assume that there exists a function $\rho\left(\omega_{m}, \omega_{f}, h_{m}, \mu\right)$ such that

$$
\omega_{m} h_{m}+\rho\left(\omega_{m}, \omega_{f}, h_{m}, \mu\right)=\psi\left(w_{m}, w_{f}, h_{m}, y\right)
$$

in which $\omega_{m}, \omega_{f}$ and $\mu$ are the virtual wage rates and nonlabour income defined earlier. The virtual wage rates and the nonlabour income are, in general, functions of $\left(w_{m}, w_{f}, h_{m}, h_{f}, y\right)$, the gross wage rates, working hours, and the household's nonlabour income. Note that in this notation the wife's share is $\mu-\rho=\mu\left(w_{m}, w_{f}, h_{m}, h_{f}, y\right)-$ $\rho\left(\omega_{m}, \omega_{f}, h_{m}, y\right)$. Note that the sharing rule $\rho($.$) describes for each combination of work-$ ing hours, wage rates and nonlabour income how the household income is allocated between husband and wife. The collective discrete hours decision problem can be represented by two individual decision problems, conditional on the sharing rule. Partner $j$ in the household chooses his or her working hours by solving the following problem:

$$
\begin{gathered}
\max _{h_{j} \in S} u_{j}\left(C_{j}, h_{j}\right) \\
\text { subject to } C_{j}=\omega_{j} h_{j}+\rho_{j}\left(\omega_{m}, \omega_{f}, h_{m}, \mu\right) \\
\omega_{j}=\omega_{j}\left(w_{m}, w_{f}, h_{m}, h_{f}, y\right), \mu=\mu\left(w_{m}, w_{f}, h_{m}, h_{f}, y\right) \\
\rho_{m}=\rho, \rho_{f}=\mu-\rho \\
j=m, f
\end{gathered}
$$

Note that the decision problem described in (5) somehow resembles a repeated game. Both partners know the sharing rule and incorporate what the other partner will do in response to their choice of working hours. ${ }^{13}$

\subsection{Choice probabilities and identification of the sharing rule}

In the continuous hours context Chiappori (1988) derives the identification of the sharing rule (up to an additive constant). He shows that the impacts of wage rates and nonlabour income on the sharing rule are nonparametrically identified. With a sample

\footnotetext{
${ }^{13}$ Chiappori et al. (2002) emphasized, among others, in their empirical application the importance of having 'stable' households in the sample, in which the partners know each other for quite some years, which makes it more likely that the hypothesis of efficiency in the intrahousehold decision process is satisfied.
} 
of observations on working hours, wage rates, and nonlabour income of working couples, we can identify the impacts of wage rates and nonlabour income on each partner's working hours. The identification of the sharing rule stems from restrictions that the collective framework imposes on the way these variables affect working hours: the husband's (wife's) wage rate affects the working hours of the wife (husband) only through the sharing rule, whereas the shares of husband and wife add-up to nonlabour income. Exploiting these restrictions, the impact of wage rates and nonlabour income on working hours can be decomposed into their impact on the sharing rule and their impact on working hours through the individual labour supply equation. Now that we are working with a discrete choice framework, the original identification result cannot be directly applied anymore. However, it is not hard to point at the similarities between the identification in the continuous hours model and the discrete choice model. In a discrete choice framework, instead of measuring the impact of wage rates and nonlabour income on (expected) working hours, we measure the impact of these variables on the choice probabilities of different categories of working hours. The collective model then predicts that the other partner's wage rate enters the choice probability of a specific number of working hours by the sharing rule, and places restrictions on the way in which nonlabour income enters the choice probabilities. Consequently, a formal proof of (nonparametric) identification may show that information on the empirical frequency distribution of different hours categories, wage rates, and nonlabour income, together with the collective restrictions of the impact of the latter variables on the choice probabilities, can be used to identify the effects of the wage rates and nonlabour income on the sharing rule. Additional complications arise due to the tax system and non-linear budget constraint. Donni (2003) conditions for identification for that case. It is beyond the scope of this applied paper to prove nonparametric identification. Instead, we will choose functional forms for the utility function and the distribution of stochastics, and we will show that from the reduced form parameters that measure the effects of wage rates and nonlabour income on the choice probabilities, we can recover the parameters that measure the effects of these variables on the sharing rule. 


\section{Econometric specification}

\subsection{The error structure}

Cf. Van Soest (1995) we add an error term, distributed according to the extreme value distribution, to the utility levels of each working hours level from the choice set. Suppose that the observed numbers of working hours of husband and wife are $h_{m}^{k}$ and $h_{f}^{l}$ respectively, with $k, l \in\{0, \ldots, H\}$. We denote the utility of husband and wife by

$$
\begin{gathered}
u_{m}\left(C_{m}^{k l}, h_{m}^{k}\right)=u_{m}^{k l}\left(\nu_{m}\right)+\epsilon_{m}^{k} \\
u_{f}\left(C_{f}^{l k}, h_{f}^{l}\right)=u_{f}^{l k}\left(\nu_{f}\right)+\epsilon_{f}^{l} \\
k, l \in\{0, \ldots, H\}
\end{gathered}
$$

The superscripts $k l$ and $l k$ denote that the values of the utility levels depend on $h_{m}^{k}$ and $h_{f}^{l}$, whereas $\nu_{m}$ and $\nu_{f}$ represent unobserved heterogeneity affecting preferences but not specific to the hours category chosen. For the additive error terms $\epsilon_{m}^{k}$ and $\epsilon_{f}^{l}$ we make the following assumptions: (i) $\epsilon_{j}^{r}, j=m, f, r=0, \ldots, H$, are independently and identically distributed according to the extreme value distribution; (ii) $E\left(\epsilon_{j}^{r} \mid h_{m}, h_{f}, w_{m}, w_{f}, y\right)=$ $0, j=m, f, r=0, \ldots, H$.

The combination of working hours $h_{m}^{k}$ and $h_{f}^{l}$ is observed if two conditions are met simultaneously. For the wife, we have

$$
u_{f}^{l k}\left(\nu_{f}\right)+\epsilon_{f}^{l}>u_{f}^{s k}\left(\nu_{f}\right)+\epsilon_{f}^{s}, s \neq l, s=0, \ldots, H
$$

whereas for the husband

$$
u_{m}^{k l}\left(\nu_{m}\right)+\epsilon_{m}^{k}>u_{m}^{r l}\left(\nu_{m}\right)+\epsilon_{m}^{r}, r \neq k, r=0, \ldots, H
$$

The parameters entering the wife's utility $u_{f}^{l k}\left(\nu_{f}\right)$ can be estimated by formulating the probability that (7) occurs and applying maximum likelihood estimation. Denoting this probability by $p_{f}^{l k}\left(\nu_{f}\right)$ we get

$$
p_{f}^{l k}\left(\nu_{f}\right)=\frac{\exp \left(u_{f}^{l k}\left(\nu_{f}\right)\right)}{\sum_{s=1}^{H} \exp \left(u_{f}^{s k}\left(\nu_{f}\right)\right)}, l=0, \ldots, H
$$

The probabilities add up to 1 over hours levels $l=0, \ldots, H$. Integration over the unobserved heterogeneity $\nu_{f}$ determines the final expression for the probability. Similarly, we 
can estimate the parameters entering (8) based on the probabilities

$$
p_{m}^{k l}\left(\nu_{m}\right)=\frac{\exp \left(u_{m}^{k l}\left(\nu_{m}\right)\right)}{\sum_{r=1}^{H} \exp \left(u_{m}^{r l}\left(\nu_{m}\right)\right)}, k=0, \ldots, H
$$

Also the probabilities (10) add up to 1 over the hours categories $k=0, \ldots, H$, and we will integrate over the unobserved heterogeneity $\nu_{m}$. Thus, maximum likelihood estimation can always be based on the probabilities (10) and (9). The question is whether we can improve efficiency by formulating the joint probability $p_{m f}^{k l}\left(\mu_{m}, \nu_{f}\right)$ that $(7)$ and (8) are satisfied simultaneously, with

$$
p_{m f}^{k l}\left(\mu_{m}, \nu_{f}\right)=p_{m}^{k l}\left(\nu_{m}\right) p_{f}^{l k}\left(\nu_{f}\right), k=0, \ldots, H, l=0, \ldots, H
$$

Now integration over $\nu_{m}$ and $\nu_{f}$ involves the joint distribution $g\left(\nu_{m}, \nu_{f}\right)$ of $\left(\nu_{m}, \nu_{f}\right)$, unlike in the separate expressions (9) and (10), which involve the integration over the marginal distributions only:

$$
p_{m f}^{k l}=\iint p_{m f}^{k l}\left(\mu_{m}, \nu_{f}\right) g\left(\nu_{m}, \nu_{f}\right) d \nu_{m} d \nu_{f}, k=0, \ldots, H, l=0, \ldots, H
$$

The question is whether the outcome of (7) and (8) is unique. By uniqueness we mean that for given values of $\epsilon_{f}^{s}, s=0, \ldots, H$ and $\epsilon_{m}^{r}, r=0, \ldots, H$ the observed hours combination $\left(h_{m}^{k}, h_{f}^{l}\right)$ is the unique combination of male and female working hours that satisfies (7) and (8) simultaneously. In other words, there is no other pair of working hours $\left(h_{m}^{r}, h_{f}^{s}\right), r \neq k, s \neq l$ which also satisfies (7) and (8) simultaneously for the same values of the errors. To explain this issue further, let us consider (7). First note that if (7) is satisfied for a given hours level $h_{m}^{k}$ for certain values of $\epsilon_{f}^{s}, s=0, \ldots, H$, the outcome $h_{f}^{l}$ is unique. Now the question is how the wife's optimal choice of working hours depends on the husband's level of working hours. Is the outcome $h_{f}^{l}$ still optimal, for a different value of the hours of the husband, say $h_{m}^{j}, j \neq k$, at the same values of $\epsilon_{f}^{s}, s=0, \ldots, H$ ? The answer depends on how the hours level of the husband affects the utility level of the wife. From the decision problem (5) we see that the hours level of the husband affects the wife's utility level not by preferences, but by the sharing rule and, possibly, by the tax system, if the tax system is such that the hours of the husband affect the virtual wage rates and non-labour income of the wife. If the utility of the wife is monotonous in 
the hours of the husband, we have a sufficient condition for the uniqueness of the hours level $h_{f}^{l}$ for all possible hours level of the husband, at given values of $\epsilon_{f}^{s}, s=0, \ldots, H$. But even if at hours $h_{m}^{j}, j \neq k$ and values of $\epsilon_{f}^{s}, s=0, \ldots, H$, hours $h_{f}^{s}, s \neq l$ are optimal for the wife, the outcome of (7) and (8) is not necessarily unique. We also need that at given values $\epsilon_{m}^{r}, r=0, \ldots, H$ for which (8) is satisfied, (that is, $h_{m}^{k}$ is optimal at $h_{f}^{l}$ ) $h_{m}^{j}, j \neq k$ is optimal at $h_{f}^{s}, s \neq l$, for the same $j$ and $s$ as above. Again, uniqueness of the outcome $h_{m}^{k}$ for arbitrary values of the wife's hours depends on how the wife's hours influence the husband's decision problem, as described in (5). From (5) we see that wife's hours possibly influence the husband's utility by the virtual wage rates, and the virtual non-labour income. So it depends on the properties of the tax system and the shape of the sharing rule whether the outcome of (8) and (7) will be unique. Now we could formulate sufficient conditions for the uniqueness of a solution, like having a utility level that is monotonously increasing in consumption, with a convex tax system, but empirically we may not want to impose these restrictions a priori. A consequence of possibly having multiple solutions is that the joint probabilities in (11) and (12) may add up to an amount larger than 1 (added up over male hours, $k=0, \ldots, H$, and female hours $l=0, \ldots, H)$. As a result, we cannot use the joint probability in the estimation of the model: applying maximum likelihood will bias outcomes in the direction of the regime where probabilities add up to values larger than one. However, we can use the probabilities for the separate condition (10) and (9). This will come at the cost loosing efficiency in the estimation. For instance, using the separate conditions (10) and (9) precludes the estimation of a correlation between the unobserved heterogeneity $\nu_{m}$ and $\nu_{f}$ of men and women.

\subsection{The wage equation}

For individuals who do not work, or individuals who do work but have missing information on wages, the gross wage rate is not observed. We formulate the following equation for the gross wage rate:

$$
\ln w_{j}=\eta_{j}^{\prime} x_{j}+v_{j}, j=m, f
$$


In (13) $\eta_{j}$ is the parameter vector measuring the impact of the observed characteristics $x_{j}$ on the gross wage rate, whereas $v_{j}$ is a random error. We assume that $v_{j}$ follows a normal distribution with mean zero and covariance $\tau_{j}^{2}$. For each household member we specify a selection equation for the labour market state with an error term that is jointly normally distributed with the error term in the wage equation (13). ${ }^{14}$ We estimated the parameters of the wage equation and the selection equation jointly with maximum likelihood. Note that the selection equation should include the variables included in the utility function. Since the choice of one partner may also depend on the wage of the other, we also include all the covariates of the partner's wage equation in the selection equation.

\subsection{The utility function}

We represent preferences by the following quadratic direct utility function: ${ }^{15}$

$$
\begin{aligned}
& u_{j}^{k l}=\left(\beta_{0, h h}^{j}+\beta_{h h}^{j} z_{j}\right)\left(\ln \left(T-h_{j}^{k}\right)\right)^{2}+\beta_{c h}^{j} \ln \left(T-h_{j}^{k}\right) C_{j}^{k l}+\beta_{c}^{j} C_{j}^{k l}+ \\
& +\beta_{c c}^{j}\left(C_{j}^{k l}\right)^{2}+\left(\beta_{0 h}^{j}+\beta_{h}^{j} z_{j}+\nu_{j}\right) \ln \left(T-h_{j}^{k}\right), j=m, f
\end{aligned}
$$

In (14) $z_{j}$ represents a vector of observable taste shifters that may influence the preferences for leisure, ${ }^{16}$ whereas $\beta_{0, h h}^{j}, \beta_{h h}^{j}, \beta_{\nu}^{j}, \beta_{c h}^{j}, \beta_{c}^{j}, \beta_{c c}^{j}, \beta_{0, h}^{j}$ and $\beta_{h}^{j}$ are the parameters of the utility function. $T$ represents the total time available. It is set to 168 hours a week in the empirical application. The utility function contains an unobserved taste shifter $\nu_{j}$. We allow for correlation between the unobserved taste shifter of husband and wife, and we assume that it is normally distributed:

$$
\left(\begin{array}{c}
\nu_{m} \\
\nu_{f}
\end{array}\right) \sim N\left(\left(\begin{array}{c}
0 \\
0
\end{array}\right),\left(\begin{array}{cc}
\sigma_{\nu, m}^{2} & \sigma_{\nu, m f} \\
\sigma_{\nu, m f} & \sigma_{\nu, f}^{2}
\end{array}\right)\right)
$$

\footnotetext{
14 Similar approaches are followed by Van Soest (1995).

15 Van Soest (1995) specifies a discrete utility function that is log-quadratic in its arguments. However, in our model, based on the collective approach, the consumption level of a household member is equal to his or her earnings plus the share of non-labour income, determined by the sharing rule. The intercept of the sharing rule is (non-parametrically) not identified, since the only restriction imposed is adding-up across household members. Consequently, the sharing rule need not be positive. Therefore we include consumption in levels.

16 We could have made the utility specification even more flexible, by making the parameters of consumption, $\beta_{c}^{j}$ and $\beta_{c c}^{j}$ a function of the taste shifters $z_{j}$. But in the present specification, the marginal rate of substitution between consumption and leisure already is a function of the taste shifters $z_{j}$ and also making $\beta_{c}^{j}$ and $\beta_{c c}^{j}$ a function of the taste shifters $z_{j}$ a function of taste shifters would make both the numerator and the denominator of the marginal rate of substitution a function of the taste shifters, which looks like overparametrizing the model.
} 
We denote the density function of random preferences by $g\left(\nu_{m}, \nu_{f} ; \Sigma_{\nu}\right)$, where $\Sigma_{\nu}$ represents the covariance matrix. The covariance parameter $\sigma_{\nu, m f}$ cannot be identified if we use the separate probabilities (10) and (9). That is part of the efficiency loss we have to incur.

It is straightforward to show that the utility function (14) is increasing in consumption if and only if

$$
\beta_{c h}^{j} \ln \left(T-h_{j}^{k}\right)+\beta_{c}^{j}+2 \beta_{c c} C_{j}^{k l}>0, j=m, f
$$

In the estimation, (16) is not a priori imposed, but the welfare levels are difficult to interpret as such if (16) is not satisfied. Therefore, in the evaluation of the model outcomes, we abstain from drawing conclusions from the welfare levels.

Utility is increasing in leisure $l=T-h$ if

$$
2\left(\beta_{0, h h}^{j}+\beta_{h h}^{j} \prime z_{j}\right) \ln \left(T-h_{j}^{k}\right)+\beta_{c h}^{j} g\left(C_{j}^{k l}\right)+\left(\beta_{0 h}^{j}+\beta_{h}^{j} z_{j}+\nu_{j}\right)>0, j=m, f
$$

Quasi-concavity is satisfied if

$$
-\frac{1}{U_{c}^{j}}\left(\begin{array}{ll}
-\frac{U_{l}^{j}}{U_{c}^{j}} & 1
\end{array}\right) H U^{j}\left(\begin{array}{ll}
-\frac{U_{l}^{j}}{U_{c}^{j}} & 1
\end{array}\right)^{\prime}>0, j=m, f
$$

with $U_{c}^{j}$ and $U_{l}^{j}$ the partial derivative of utility with respect to consumption and leisure, and $H U^{j}$ the hessian of the utility function with respect to consumption and leisure.

\subsection{Specification of the sharing rule}

In the previous section we have noticed that the sharing rule in this discrete choice setting is not only a function of the (virtual) wage rates of husband and wife and the (virtual) nonlabour income of the household, but is also a function of the working hours of the husband. ${ }^{17}$ Accordingly, we specify the following sharing rule: ${ }^{18}$

$$
\begin{aligned}
& \rho\left(\omega_{m}, \omega_{f}, h_{m}, \mu\right)= \\
& \alpha_{0}+\alpha_{1} \omega_{m} h_{m}+\alpha_{2} w_{m}+\alpha_{3} w_{f}+\alpha_{4} \mu+\alpha_{5} D+\alpha_{6} h_{m}+\alpha_{7} \mu^{2}
\end{aligned}
$$

\footnotetext{
17 In their model of restricted choice by the husband, Blundell et al. (2007) actually specify two separate sharing rules for the two choice opportunities ( 0 or 40 hours) of the husband.

18 In the empirical application we will allow the parameters of the sharing rule to be different by marital status.
} 
Note that we included the virtual labour income $\omega_{m} h_{m}$ of the husband. In individual models for the labour supply of married women, the labour income of the husband appears as an explanatory variable, usually added together with non-labour income of the household. The present specification therefore nests this case and links the parameters to the husband's choice. The variable $D$ is a factor that represents the relative bargaining power of husband and wife, and we specify

$$
D=\frac{\omega_{m}}{\omega_{m}+\omega_{f}}
$$

Recall that $\rho=\rho_{m}$, the husband's share, while the wife's share follows from (19) as $\rho_{f}=\mu-\rho_{m}$. Moreover, by the budget constraint, $C_{j}=\omega_{j} h_{j}+\rho_{j}, j=m, f$. Note that a necessary condition for income pooling is $1+\alpha_{1}=\alpha_{4}$.

Note that in the estimation of the model data on several years are used. Throughout we assume that the parameters of the sharing rule $\alpha_{j}$ remain constant across time. Thus, we implicitly assume that there is no renegotiation on the shape of the sharing rule if the value of any of the variables entering the sharing rule changes across time. In other words, the marginal effects of the variables affecting the share remain constant. Only changes across time in the levels of the variables affect the division of income between household members. In the empirical specification, though, we experimented with sharing rule parameters that change over time. We will comment on the outcomes in the results section.

\subsection{Identification}

Constructing the consumption levels $C_{j}=\omega_{j} h_{j}+\rho_{j}, j=m, f$ using the sharing rule (19) imposes parameter restrictions between the consumption levels of husband and wife. To make these restrictions explicit, we specify the 'reduced form' consumption functions $X_{m}$ and $X_{f}$ for husband and wife:

$$
X_{m}=\gamma_{1}^{m} \omega_{m} h_{m}+\gamma_{2}^{m} \omega_{m}+\gamma_{3}^{m} \omega_{f}+\gamma_{4}^{m} \mu+\gamma_{5}^{m} D+\gamma_{6}^{m} h_{m}+\gamma_{7}^{m} \mu^{2}
$$

and

$$
X_{f}=\gamma_{0}^{f} \omega_{f} h_{f}+\gamma_{1}^{f} \omega_{m} h_{m}+\gamma_{2}^{f} \omega_{m}+\gamma_{3}^{f} \omega_{f}+\gamma_{4}^{f} \mu+\gamma_{5}^{f} D+\gamma_{6}^{f} h_{m}+\gamma_{7}^{f} \mu^{2}
$$


Before continuing, we would like to emphasize that the purpose of this section is to shed light on the identification, and not to set up a specification for the purpose of estimation. The reduced form specifications contain too much parameters and yield, in practice, an overparametrized model with flat likelihood functions. We will therefore not test the restrictions.

We specify the reduced form utility functions as

$$
\begin{aligned}
& U_{j}^{* k l}=\beta_{h h}^{j}\left(\ln \left(T-h_{j}^{k}\right)\right)^{2}+\beta_{* c h}^{j} \ln \left(T-h_{j}^{k}\right) X_{j}^{k l}+\beta_{* c}^{j} X_{j}^{k l}+ \\
& +\beta_{* c c}^{j}\left(X_{j}^{k l}\right)^{2}+\left(\beta_{0 h}^{j}+\beta_{h}^{j} z_{j}+\nu_{j}\right) \ln \left(T-h_{j}^{k}\right), j=m, f
\end{aligned}
$$

In (14) the superscript $k l$ indicates, as before, that utility is evaluated in hours levels $h_{m}=h_{m}^{k}$ and $h_{f}=h_{f}^{l}$.

Let us concentrate on the parameters of the sharing rule. (For the moment we keep the parameters of the utility function constant). We count 15 reduced from parameters: $\gamma_{l}^{f}, l=0, \ldots, 7$ and $\gamma_{l}^{m}, l=1, \ldots, 7$. The 'structural' sharing rule has 7 parameters: $\alpha_{l}, l=1, \ldots, 7$. We first express the reduced form parameters in the structural parameters. For the husband's consumption parameters we have

$$
\gamma_{1}^{m}=1+\alpha_{1}, \gamma_{j}^{m}=\alpha_{j}, j=1, \ldots, 7
$$

For the wife's consumption parameters the following restrictions hold:

$$
\gamma_{0}^{f}=1, \gamma_{j}^{f}=-\alpha_{j}, j=1,2,3,6,7, \text { and } \gamma_{4}^{f}=1-\alpha_{4}
$$

Note that the reduced form parameter $\gamma_{1}^{m}$ is not identified without imposing the addingup restriction $\gamma_{1}^{m}+\gamma_{1}^{f}=1$. From (24), and (25) we can solve the 7 structural parameters, and 8 cross equation restrictions:

$$
\alpha_{j}=-\gamma_{j}^{f}, j=1,2,3,5,6,7 \text { and } \alpha_{4}=1-\gamma_{4}^{f}
$$

and

$$
\begin{aligned}
& \gamma_{j}^{m}=-\gamma_{j}^{f}, j=2,3,5,6,7 \\
& \gamma_{j}^{m}+\gamma_{j}^{f}=1, j=1,4, \gamma_{0}^{f}=1
\end{aligned}
$$

Note that the restrictions imposed this way can only be estimated if we use a model for both husbands and wives. A different approach in the literature, see for instance, 
Vermeulen (2006), and Beninger and Laisney (2002), is uses information of women only and identify parameters by comparing married and single women. The restrictions tested and imposed in this approach usually are restrictions on the utility function of the wife herself, rather than restrictions between husband and wife.

\subsection{Fixed costs of work}

Previous studies that use the discrete hours framework reveal that the discrete choice model, once the parameters have been estimated, typically fails to predict the sample fraction of non-working individuals (see Van Soest, 1995, and the remarks in Beninger and Laisney, 2002). This led to the practice of introducing fixed costs of work (see, for instance, Van Soest and Das, 2001). Fixed costs of work are not directly observed, but parametrized by allowing for a fixed discrete difference in the consumption level between labour market states. Suppose that the fixed cost of work of household member $j(j=m, f)$ is $F_{j}$. To introduce fixed costs we will assume that the income available for consumption is $C_{j}=\omega_{j} h_{j}+\rho_{j}-F_{j} \iota\left(h_{j}>0\right), j=m, f$. Note that we assign the fixed cost of household member $j$ completely to the consumption of household member $j$ and not to the partner. This is motivated by the double indifference condition, which implies that the sharing rule should be a continuous function of the amounts of fixed costs of both partners (i.e. the amounts should enter the sharing rule for both working and non-working individuals). But if the amounts are fixed, and if there are no variables that affect fixed costs of work and not the marginal utility of working hours we cannot identify fixed costs of work from the sharing rule, as the sharing rule is identified up to an additive constant only. Therefore, the fixed costs of work only enter the individual consumption levels.

Adding fixed cost solves at least part of the misprediction of the fraction of nonworking in the discrete choice hours model. We want to emphasize that it is an ad hoc solution, but it has become common practice in the literature on discrete hours models. ${ }^{19}$

\footnotetext{
${ }^{19}$ In different contexts, alternatives for a fixed cost are imaginable. For instance, Bloemen (2008) specifies a search model for unemployed job searchers, that includes working hours as a job characteristic. In that framework, unemployment benefits as well as job offer restrictions give a very natural explanation for observing someone with zero working hours, apart from the choice explanation. The need for adding ad hoc fixed cost is not very strong in such a framework.
} 
Bloemen and Kapteyn (2008) also studied the performance of fixed costs in the discrete choice framework. In the Monte Carlo study, they find that fixed costs turn out to be significant, even if the underlying 'true model' did not contain fixed costs. Therefore, we should be careful with interpreting the estimated value of the fixed costs, and we may at best regard the introduction of fixed costs as a flexibilisation of the utility function.

\section{The income tax system in the Netherlands}

We will use information for the years 1990-2001. In the years 1990-2000 the rules of the Dutch income tax system were basically the same. There are, though, year to year differences in marginal tax rates and standard deductibles, which mainly represent corrections for inflation. For household labour supply decisions it is important to note that in the Dutch tax system individual incomes are taxed. Every individual has a standard deductible: ${ }^{20}$ the marginal tax rate for any income below this amount is zero. There is some relation between the income taxation of two partners in a household. Only if a household member earns an income that is below the standard deductible, s/he can transfer the amount of the standard deductible to her/his partner, who can add it to his/her deductible. This raises household income if the partner earns more than the deductible. Transferring the deductible to the higher income partner, if the household is eligible for it, is the common practice among households in the Netherlands. In the years 1998 through 2000 the deductible was split up into a small non-transferable deductible ${ }^{21}$ and the transferable deductible. In 1990 through 1998 there were three tax brackets for the income net of the deductible. ${ }^{22}$ In 1999 a fourth income tax bracket was introduced. The marginal tax rate for the first bracket varies from year to year, because it partly consists of premiums for social welfare. The marginal tax rate for the two higher brackets remained at $50 \%$ and $60 \%$ throughout the years, except for 2001, for which the values are $42 \%$ and $52 \%$. Table 1 shows the standard deductibles throughout the years 1990 2000. As an example, consider the year 1997 and suppose that the wife earns less than

\footnotetext{
${ }^{20}$ The Dutch terminology in the law is the 'basisaftrek'.

${ }^{21}$ The so called 'bovenbasisaftrek'.

22 The 'belastbare som'.
} 
7102 guilders a year. ${ }^{23}$ Then she may transfer the full deductible amount of 7102 to her husband. She will then have a deductible of zero, whereas the deductible for her husband will be 14204 guilders. The advantage for the household income as a whole is (i) that the complete deductible amount of 7102 is exploited ${ }^{24}$ and (ii) if the husband is in the second or third tax bracket there is an additional gain since on the margin the husband's income is taxed at a higher rate than the wife's income as the tax system is progressive. Van Soest and Das (2001) plotted the impact of transferring the deductible to the other partner on the budget constraint for the year 1998. The shape of the budget constraint shows a nonconvex kink at low numbers of working hours, but the nonconvexity is rather small.

From the year 2001 on the system of deductibles changed. The standard deductible was replaced by a system of deductibles that depend on the personal situation, like the labour market status, presence of children in the household, households with lone parents, households with old aged, and so on. A base deductible remained but was lower than before. The transferability of the deductible from one partner to the other was abolished. For working couples without children the relevant deductibles are the base deductible and the labour market state dependent deductible. Table 1 shows these deductibles for the year 2001, as well as the marginal tax rates for the first two brackets. Note that the introduction of the labour market state dependent deductible has implications for the specification of the sharing rule. The labour market state dependent deductible has a similar implication as fixed costs of work, as discussed previously. Double indifference implies that the sharing rule has to be a continuous function of the deductible amount, i.e. the deductible amount has to be included in the sharing rule for both labour market states. Since the deductible amount is the same for everybody, this implies that the intercept of the sharing rule is affected by the introduction of the labour market state dependent deductible. Although the intercept of the sharing rule by itself is not identified, the intercept for the year 2001 is potentially different from that of the previous years. Therefore, in (19) a dummy variable for the year 2001 may

\footnotetext{
${ }^{23}$ Note that someone can never deduct more than the value of her/his income.

${ }^{24}$ For instance, if the wife's income is 6000 guilders, she can only deduct these 6000 .
} 
be included. Alternatively, we may guess that the change in the tax system leads to rebargaining and therefore a new sharing rule, or, new values for the parameters of the sharing rule. We will discuss the issue of time dependent sharing rule parameters in the empirical section. ${ }^{25}$

\section{The data}

We use data from the Socio-Economic Panel (SEP). The SEP is a household survey collected by Statistics Netherlands. We use data for the years 1990 to 2002. In this period, households were interviewed on a yearly basis, every May. The income in a given survey wave refers to the previous calendar year: the income information in the survey is based on the income information that individuals provided to the tax administration for determining income taxes for the previous year, which typically has to be finished and returned to the tax authorities by April. For this reason, we link data from two subsequent waves to get the complete information for one year. Consequently, for each individual we have information for the years 1990 through 2001.

For each year, we selected couples living together (either married or unmarried) without children, in which the male is in the age range of 22 to 60 and the female is no older than $60 .{ }^{26}$ We excluded households in which either husband or wife reports to be selfemployed. Furthermore, we require the availability of information on the labour market state of both household members, the non-labour income, and information on the level of schooling and the sector of education. We use information on hourly wage rates and employment status for the estimation of the wage equation. The pooled dataset contains 8049 observations (in which the observation unit is the two-member household).

Table 3 contains descriptive statistics for the pooled data. Note that $86.3 \%$ of the male respondents is employed and $72.5 \%$ of their female partners. In interpreting these numbers we should recall that we selected couples without children. Therefore, the percentage of working females is relatively high in our sample. At the household level we see that in $66.9 \%$ of the households both spouses are working and in $19.5 \%$ of the

\footnotetext{
${ }^{25}$ In advance, we can say that identification of such age dependent parameters failed in practice.

26 The age of 60 was the most common age for eligibility to early retirement in the Netherlands.
} 
households the husband works, while the wife does not. For $8.1 \%$ of the households none of the members is working, whereas in only $5.6 \%$ of the households only the wife works.

Note that on average the males in the sample are higher educated than the females. We have also information about the direction, or sector, of education and here we see some typical differences between males and females. There are few women with a technical type of education whereas the majority of the men followed a technical education. The majority of women is educated for the service sector. There are also more women without specialization in education. The mean age for males is about 2 years higher than for females, which is quite common for married couples.

Mean weekly working hours for males are about 40, whereas females work 31 hours a week on average. The male hourly wage rate is more than 2 guilders higher than the wage rate of females. The non-labour income includes interest income, income out of real estate, rent subsidy, income out of life insurance, ${ }^{27}$ gifts by family, dividend income and income out of profits and scholarships. In the survey it is measured on a yearly basis and in Table 1 it is converted to guilders per week. The average is about 37 guilders a week, and there is quite some variation in it, with some households reporting much higher amounts, and some households reporting not to have received any non-labour income.

We have classified working hours into intervals of 6 hours, and such that the most prevailing working hours levels have a separate category. ${ }^{28}$ Zero working hours is treated as a separate class. We have a somewhat different classification for men and women, since there are hardly any women working more than 40 hours a week. If $h_{m}^{k}$ denotes the classified hours value for men and $h$ is the observed value, then we classify $h$ (for men) as follows:

$$
\begin{aligned}
& h_{m}^{k}=h_{m}^{0}=0 \text { if } h=0 \\
& h_{m}^{k}=6 k-3 \text { if } 6(k-1)<h \leq 6 k, k=1, \ldots, 10 \\
& h_{m}^{11}=63 \text { if } h>60
\end{aligned}
$$

\footnotetext{
27 'Lijfrente'.

28 For instance, part-time jobs of 20 hours a week and 24 hours a week (3 days) are included in category $k=4$, jobs of 4 working days a week are included in category $k=6$, while full-time jobs of 38-40 hours a week are included in category $k=7$.
} 
For women, we have the same classification, but because of the small number of observations with a high number of working hours, we take $h>48$ as the top category:

$$
\begin{aligned}
& h_{f}^{k}=h_{f}^{0}=0 \text { if } h=0 \\
& h_{f}^{k}=6 k-3 \text { if } 6(k-1)<h \leq 6 k, k=1, \ldots, 8 \\
& h_{f}^{9}=51 \text { if } h>48
\end{aligned}
$$

\section{Estimation results}

First, the parameters of the wage equations were estimated by maximum likelihood, using a reduced form participation equation. The procedure is described in detail in Appendix A, and the estimates of the employment and wage equation are in the tables A.1 and A.2. The results were used to predict wages.

During the estimation of the discrete hours model we found that the variance of the unobserved heterogeneity for men, $\sigma_{\mu, m}$, in (15) converged to zero for men. ${ }^{29}$ Apparently hours of men do not exhibit sufficient variation to be able to identify unobserved heterogeneity from the data, in addition to the observed characteristics included in the model. For this reason we excluded the unobserved heterogeneity for men from the model and the model was estimated with unobserved heterogeneity for women only.

For reasons of comparison, several versions of the model were estimated. As a reference case we took a restricted version of the sharing rule that imposes income splitting behaviour with regard to non-labour income and the husband's earnings. For this purpose we set $\alpha_{1}=-0.5, \alpha_{4}=0.5, \alpha_{j}=0, j=2,3,5,6,7$ in the sharing rule (19) specification. This type of specification is consistent with female labour supply models that treat the husband's earnings as a source of non-labour income to the wife.

Next, we took the more flexible specification of the sharing rule in (19), with parameters that vary with marital status. In addition, each variant was estimated with and without fixed costs. The results of the estimation are shown in Tables 4 through 7.

Table 4 contains the base parameters of the utility function for each specification, Table 5 presents the parameters of the fixed costs (for the fixed costs specifications),

\footnotetext{
29 This phenomenon is often found in applications of the discrete choice model of labour supply. See Bloemen and Kapteyn (2008) for a discussion.
} 
and Table 6 shows the parameters of the sharing rule (for the model variants with an unrestricted sharing rule). Finally, Table 7 contains the parameters of the taste shifters for each variant. Most of the parameters are not directly interpretable themselves, so we are looking for ways to evaluate the estimation results obtained with the different model variants.

Since the model variants are nested, likelihood ratio test statistics seem to provide an obvious way to compare and evaluate different specifications. But a discrete choice labour supply model specifies probabilities of finding working hours in given hours categories, so any flexibilization of the model brings the discrete choice hours distribution implied by the model closer to its corresponding empirical distribution function, and it will be no surprise to find significantly better likelihood values for more flexible specifications. An inspection of the likelihood values showed us that this happens, indeed. Since we are modelling household behaviour, the more relevant question is whether a more flexible model specification implies different choice outcomes for the household members or a different allocation of income between husband and wife. The wage elasticities of labour supply provide a means of summarizing the model outcomes. The estimation of wage elasticities is not specific to collective models of household labour supply, so results can be compared with earlier results from the literature. Next we evaluate how the allocation of income to husband and wife changes as a consequence of changes in husband's and wife's (gross) wage rates. The outcomes are influenced by the tax system and the sharing rule. We evaluate whether results are different if a flexible sharing rule specification is chosen or a restricted specification. Finally, we simulate a change in the tax system that is similar to the actual policy change that took place in the Netherlands in the year 2001. We will evaluate how this affects the income sharing between husband and wife, and whether different model specifications lead to different hours responses.

The order of the presentation of results is as follows. In sections 6.1 and 6.2 we will briefly discuss the parameter estimates themselves. Section 6.3 presents wage elasticities of labour supply. In section 6.4 we discuss marginal effects of husband's and wife's wage rates on the allocation of income. Section 6.5 presents results of the simulation with the tax system. 


\subsection{Parameter estimates: the taste shifters}

Before discussing the more fundamental results, we take a look at the taste shifters. Tables $7 \mathrm{a}$ through $7 \mathrm{~d}$ contain the estimates. We comment on the two specifications with an unrestricted sharing rule. The parameter estimates are hard to interpret by themselves, but their impact becomes clear once we realize how they affect the marginal utility of leisure. The base parameters of the marginal utility of leisure are $\beta_{0, h h}^{j}$ and $\beta_{0 h}^{j}, j=m, f$ (see Table 4). The parameters in Table 7 show the deviations from this base. We computed the marginal utility of leisure for working hours levels of 40 for men and 32 for women (which correspond to the average levels of working hours for employed men and women).

For men, the marginal utility of leisure decreases with the level of education. The coefficients measuring the effect of the wife's education level on the husband's marginal utility leisure are not all estimated precisely, but the impact is U-shaped: both men with a low educated wife and men with a highly educated wife attach more weight to leisure. Married men have a lower marginal utility of leisure, but the effect of marital status is much stronger for the variant without fixed costs. Note, though, that marital status is also included as a regressor in the fixed costs.

For women the marginal utility of leisure increases with the husband's level of education, whereas it is higher for low educated women. The impact of marital status differs between the specifications with and without fixed costs. The latter specification shows a

higher marginal utility of leisure for married women, while the effect is reversed, though not strongly, in the specification with fixed cost.

The estimates of the age coefficients imply, for the specification without fixed costs, that the marginal utility of leisure of both men and women increases with the age (at average age levels) of both husband and wife. The impact of the individual's own age is much stronger, though, especially for women. The specification with fixed costs reveals that the marginal utility of leisure of men decreases with age. Note, however, that age is also included as a regressor in the fixed costs, showing that fixed costs of men increase with age (see Table 5). 


\subsection{Parameter estimates: preferences and the sharing rule}

Table 6 shows the parameter estimates of the sharing rule. Since the parameters represent marginal effects of virtual wage rates, earnings, and non-labour income, not all parameters are directly interpretable, and in section 6.4 we will therefore discuss simulation results of changes in gross wage rates on the share. For both the variant without fixed costs and the variant with fixed costs, the parameter of the husband's earnings, $\alpha_{1}$, is smaller than -0.5 , irrespective of the marital status. This suggests that, in general, husbands transfer part of their earnings to their wives. We also see that unmarried men transfer a larger share of their earnings to their partners than married men. Something similar is happening for non-labour income: within each model specification, unmarried men transfer more of their non-labour income to their partner than married men. This suggests that married women are in a worse bargaining position than unmarried women. ${ }^{30}$ Between the specification without fixed costs and with fixed costs, there is a difference in the impact of non-labour income: men get a higher share of non-labour income in the fixed costs specification. Possibly non-labour income affects participation in the specification without costs, a role which may be taken over by the fixed costs in the fixed costs specification. More light on this will be shed in the computation of elasticities and in the simulations, described in the next sections. In all specifications we find that male working hours have a positive effect on the husband's share, suggesting that men are in a more favourable position if they work more. The husband's wage rate, expressed as a share of the sum of both partner's wage rates, $D$, is never significant and always estimated with a large standard error. ${ }^{31}$

\footnotetext{
${ }^{30}$ Qualitatively these findings are not dissimilar to the results by Bloemen (2009), who also finds, with an entirely different model specification without taxes, that husbands transfer income to their wives, and that unmarried women get a larger share of non-labour income than married women.

31 To check whether the sharing rule may have been overparametrized, we have estimated a model variant which excluded the levels of the male and female virtual wage rate, but still kept the wage rate ratio (as an expression of relative bargaining power). In these specifications the wage rate ratio $D$ was significant, but the wage elasticities of working hours and participation changed in magnitude, compared to the more flexible sharing rule, leading to the conclusion that this specification was overly restrictive.
} 


\subsection{Elasticities}

To evaluate whether different model specifications generate different outcomes, wage elasticities of working hours were computed. To this purpose, a simulation was run that increased the gross wage rates of, subsequently, men and women, by $1 \%$. Working hours of men and women were simulated from their joint distribution $(12)^{32}$ before and after the simulated wage increase. A similar simulation was run for non-labour income. Table 8 displays the results. The table shows elasticities of both working hours (including zeros) ${ }^{33}$ and participation. ${ }^{34}$ Comparing the variants without fixed costs (with a restricted and a flexible sharing rule specification), elasticities of working hours for men are somewhat different, but not that much. The flexible sharing rule estimates a positive significant own wage elasticity for men, while this elasticity is not estimated precisely for the restricted sharing rule variant. The unrestricted sharing rule exposes a lower sensitivity of male working hours to non-labour income, but in both cases the effect of non-labour income is significantly negative. A higher wage rate of the wife leads to less working hours for the husband. The restricted sharing rule shows a significantly positive and sizeable effect of the husband's own wage on participation, which disappears for the more flexible specification of the sharing rule. For women, both variants without fixed costs show positive and significant own wage effects of similar size, both for working hours and for participation. For working hours, the flexible sharing rule specification predicts a negative impact of the husband's wage rate on the wife's working hours, which we do not find for the restricted sharing rule. For both variants, we do not find significant effects of non-labour income on the wife's working hours and participation. The elasticities shown here are for the sample as a whole. Splitting up by marital status would exhibit heterogeneity in the impact of non-labour income by marital status, as can be derived from the different parameters of non-labour income by marital status. Comparing the variants with fixed costs with each other shows larger differences between the restricted sharing rule and the flexible variant. None of the hours and participation elasticities of

\footnotetext{
32 Adding up to one was imposed by normalizing the probabilities by the sum of the probabilities over all hours categories.

33 In the American literature referred to as the 'intensive and extensive margin'.

34 The 'extensive margin' only.
} 
men are estimated precisely for the flexible variant, while for the restricted variant we do find some significant effects. Also the women's own wage elasticities of working hours and participation are different. The restricted sharing rule with fixed costs is the only model variant that finds a small and insignificant elasticity of the wife's own wage on her working hours, whereas also the wage elasticity of participation is much smaller than for the other variants. From this we may conclude that the model variant with fixed costs in combination with the restricted sharing rule is too constrained.

Comparing the variants without fixed costs and with costs for the flexible sharing rule specification, the most noticeable difference is the complete insensitivity of male working hours and participation for the fixed costs specification. However, it may be noted that for all variants, the husband's elasticities are small in magnitude, even though the values are significant sometimes. For the women, the own wage elasticities of working hours and participation are of comparable size, irrespective of the inclusion of fixed costs. There are some differences in the husband's cross wage effects, though. In the fixed costs specification, the wife's working hours are less sensitive to the husband's wage rate, and the effect is also less precise. On the contrary, there is a small positive effect of the husband's wage rate on the wife's participation for the fixed costs specification.

To compare the values of the elasticities with results obtained in the literature, first note that there are more results in the literature on labour supply elasticities for females than for males. Van Soest, Woittiez, and Kapteyn (1990) estimated a wage elasticity of female labour supply of 0.45. Bloemen and Kapteyn (2008) estimate various model variants. Their variants based on simulated scores and on a flexible discrete choice model with a third order utility function on average show wage elasticities of working hours and participation of 0.42 and 0.25 . Van Soest (1995) estimates a discrete choice family labour supply model without fixed costs. He finds male's own wage elasticities of around 0.10, female's own wage elasticities of around 0.50, cross elasticities of the husband's wage rate on the wife's working hours in the range of -0.10 to -0.05 , and cross elasticities of the wife's wage rate on the husband working hours of around -0.03 . The studies mentioned all find somewhat higher own wage elasticities of the wife's working hours than we do. All the studies mentioned so far use data from the eighties for married women, when 
there was a different tax system with 10 to 11 income brackets. Bloemen (2009) finds for data from the nineties within the context of a collective regression model without taxes but with net wage rates, own wage elasticities of men that vary with marital status but are on average around 0.09, women's owns wage elasticities ranging from 0.22 to 0.60 , depending on marital status, cross elasticities of the wife's wage rate on the husband's working hours of around 0.05 , and negative cross wage elasticities of the husband's wage rate on the wife's labour supply of around -0.15 . The wage elasticity values in Table 6 do not look unreasonable given this range of values from the literature. In general, less information is available about the sensitivity of working hours and participation with respect to non-labour income. Van Soest (1995) found for the working hours of men negative (median) values around -0.03. We find values closer to zero, but always negative for men. For women, he finds (median) values ranging from -0.009 to 0.008, depending on the model specification. Here, we also find sometimes positive values of the same order of magnitude. Bloemen (2009) addresses heterogeneity by marital status and finds negative values for unmarried women and positive values for married women.

\subsection{Implications for income sharing}

The implementation of a collective labour supply model provides the opportunity to obtain results about the sharing of income between partners within a household. To make the models' implications for income sharing visible, Table 9 records the percentage households with increases in the consumption (=income) of the husband, the consumption of the wife, and the husband's share (set by the sharing rule) as a result of increases in gross wage rates of the husband, the wife, or an increase in the household's non-labour income. Table 9a records the results for the specifications with the restricted sharing rule, while Table $9 \mathrm{~b}$ shows the results with the flexible sharing rule. To obtain the results of a $1 \%$ increase in the gross wage of, say, the husband, all wages in the sample were increased by $1 \%$. We simulated the joint labour supply of husband and wife before and after this wage increase. ${ }^{35}$ Thus, the outcomes include both marginal effects, as for

\footnotetext{
35 This way, we simulated for each individual in the sample 12500 different values of working for husband and wife.
} 
instance measured by the parameters of the sharing rule, and the eventual behavioural changes in the working hours and participation.

Upon a wage increase of the husband, both variants with the restricted sharing rule show that almost all husbands in unmarried couples experience an increase in their consumption level. The same holds for married couples, but for the fixed costs variant $10 \%$ of the husbands does not experience an increase in consumption. ${ }^{36}$ The flexible sharing rules in Table $9 \mathrm{~b}$ lead to different conclusions. The variant without fixed costs shows a larger minority of around $12 \%$ of married and unmarried men that does not experience an increase in consumption upon an increase in the wage rate. For the variant with fixed costs, the results vary even more. Less than $4 \%$ of the unmarried men experiences an increase in consumption, whereas the percentage is $75 \%$ for married men: the difference between the unmarried and the married is much more pronounced for this variant. The variants with the flexible sharing rule suggest that almost all women experience an increase in consumption, irrespective of marital status and irrespective of whether or not fixed costs are included. For the restricted sharing rule, there is a larger minority of women that does not experience an increase in consumption due the increase in their husband's wage rate.

Also an increase in the wife's wage rate shows differences across specifications. For all specifications, the majority of women experience an increase in their consumption level as a result of an increase in their wage rate. In the flexible specifications, the husbands experience in general more often consumption increases, although there is a sizeable minority of 20 to $30 \%$ of men that do not experience an increase in consumption. An exception is the group of married men for the flexible specification without costs, for which the consumption of only $11 \%$ increases.

The increase in non-labour shows an increase in the consumption of almost all men and for the majority of women for the specification with the restricted sharing rule. For the unrestricted sharing rule the results are quite different. The specification without fixed costs predicts that both married and unmarried men almost all experience a decrease in consumption, whereas almost all women, irrespective of marital status, see an increase

\footnotetext{
36 The fixed costs depend on marital status.
} 
in their consumption level. The variant with fixed costs reveals considerable variation by marital status. Unmarried men do not benefit from the increase in non-labour income, only the women do, whereas in married couples both men and women experience an increase in consumption. This heterogeneity by marital status somehow resembles results in Bloemen (2009), who found that married women did not benefit from the increase in non-labour income, whereas unmarried women did, suggesting a better bargaining position for unmarried women than for married women.

Table 9 also shows the effects on the share of the husband. ${ }^{37}$ An increase in the husband's wage rate only increases the husband's share in a minority of the cases, whereas an increase in the wife's wage rate increases the husband's share more often. What matters most, though, is the change in total consumption which was discussed above. For changes in non-labour income the differences between the restricted sharing rule and the flexible sharing rule are most pronounced. For the restricted sharing rule, based on splitting of non-labour income, the share of the husband increases for almost all men. The flexible sharing rule specification predicts that an increase in non-labour income hardly increases the share of unmarried men. For married men the share increases for the majority of men according to the fixed costs specification. ${ }^{38}$ Finally, note that the results in Table 9 only address the incidence of the direction of consumption changes, and reveal nothing about the relative size. The relative size cannot be determined, as the level of the sharing rule cannot be identified. ${ }^{39}$

\subsection{Simulating the tax reform}

To show the implications of using different specifications for policy change predictions, the effects of a counterfactual policy change in the tax system were simulated. First, the tax system of the year 2000 was applied to every observation in the sample and the working hours of husband and wife were generated from its joint distribution. Next, the

\footnotetext{
${ }^{37}$ Note that the change in the share of the wife due to a change in a wage rate is not automatically the opposite of the change in the share of the husband, as changes in wage rates may shift workers to different tax brackets and therefore the value of the virtual non-labour income may change as well.

${ }^{38}$ Again, it can be noted that this result is similar to the result in Bloemen (2009), obtained with an entirely different model specification without taxes.

${ }^{39}$ Chiappori (1988).
} 
simulation was repeated, but now with the tax rules of the year 2001. The policy change in 2001 was described in Section 4. Marginal tax rates stayed the same according to this policy change, but tax allowances partly became labour market state specific to stimulate participation, opportunities to transfer deductible to the higher income partner were reduced, and the bounds of tax brackets changed. A priori it is expected that this policy change stimulates participation, notably for women. The collective model specifications can not only be used to predict the effects of the policy change on working hours and participation, but can also shed light on the implications of the policy change for the income sharing within households.

Table 10 shows the outcomes of the simulation for consumption and the share. It shows the percentage ${ }^{40}$ with increases in the consumption of husband and the wife, and the share of the husband and the wife due to changing the properties of the tax system. A difference between the specifications with the restricted sharing rule on the one hand and the flexible specification on the other, is that the restricted rule assigns a consumption increase to almost all women, irrespective of marital status. The flexible sharing rule without fixed costs is the only specification that predicts an increase in consumption for almost all men. The flexible sharing rule specification with fixed costs predicts that about the same percentage of unmarried men and women (not necessarily within the same household) experiences a consumption increase, whereas a majority of married women and a minority of married men experiences an increase in consumption. All variants, except for the flexible specification without fixed costs, show hardly any increase in the share of the husband. The flexible specification with fixed costs shows that married women do better than unmarried women in terms of consumption.

The results show that the variants with the restricted sharing rule overestimate the positive impact of the policy change for the income of women. The flexible sharing rule specifications incorporate that husbands assign income to their wives. Since the policy change may reduce deductibles for husbands more than for wives, less income is transferred to the wives for model variants with the flexible sharing rule. Since income allocation to married women is lower than to unmarried women due to a less favourable

\footnotetext{
40 Per household 12500 replications were done.
} 
bargaining position for married women, as shown by the coefficients of the sharing rule in Table 6, married women are less affected by the decrease in men's deductibles. Thus, we see that an overly restricted model that does not take into account the bargaining effects of wages and non-labour income on the introhousehold income allocation process, leads to wrong conclusions about the effects of the tax policy change for the position of women.

Table 11 shows the effects of the policy change on working hours (including zeros) and participation. It shows the change in the average number of working hours a week, and the change in participation expressed in percentage points. The fixed costs specifications show in general a lower response in terms of working hours than the specifications without fixed costs. The unrestricted sharing rule with fixed costs shows the smallest response of male participation and working hours, in accordance with the low male elasticity estimates for this variant. In general, married women show more response than unmarried women to the change in the tax rule. On average, married women are lower educated and less often employed than unmarried women, so for them tax incentives for stimulating participation and abolishing the transferability of the tax allowance to the higher income partner is likely to be more effective. Comparing the results of all the specifications, also taking into account the results in the previous subsections, we can conclude that the restricted sharing rule specifications place too heavy restrictions on the behavioural outcomes for the households. If we compare the two flexible sharing rule specifications, with and without fixed costs, the impression is that the fixed costs specification is not only more flexible, but also generates more plausible outcomes in terms of behaviour. According to this specification men hardly change their labour supply behaviour, while average weekly working hours of unmarried and married women increase by 0.4 and 1.6 hours, and participation of unmarried and married women increases by 0.5 and 5.1 percentage points. Bosch and Van der Klaauw (2009) did a policy evaluation study after the effects of the tax policy change in 2001, using administrative data about female working hours and participation before and after the policy change. They record increases in female participation rates in the range of 3 to 6 percentage points, comparable to the numbers in Table 11, and find an increase in average weekly 
working hours of 0.36 . This is close to the simulated increase in working hours for unmarried women reported in Table 11 but somewhat smaller than the simulated increase for married women. Note, though, that our sample only includes women without children. Households with children benefit in the 2001 tax system from an additional tax allowance that is not labour market state dependent, and this may reduce the sensitivity to the policy change for women with children.

\section{Conclusions}

We estimated a discrete hours choice model that incorporated income taxation, individual preferences, and income sharing between partners. The identification of the sharing rule parameters was achieved by using data on both men and women within couples. We estimated model specifications with a restricted sharing mechanism, implying that the husband's earnings are pooled together with the household's non-labour income in the female's labour market decision, and a more flexible specification, that allows for a role of individual wage rates in bargaining. We also estimated variants with and without fixed costs of work.

We evaluated the variants by analyzing behavioural outcomes, like elasticities and income allocation between partners. More restricted specifications do not always lead to different conclusions for female own wage elasticities of working hours and participation: three of the four specifications show similar values. The most notable differences are found for the income allocation between partners. Flexible specifications show a higher tendency of husbands to assign an increase in their wage rate or in the household's nonlabour income to their wives. Also the difference between married couples and unmarried couples is more pronounced, and it seems as if unmarried women have a stronger position in the income allocation process than married women. ${ }^{41}$

We simulated the effects of a tax reform, introduced in the year 2001. The reform creates additional incentives for participation, especially for (lower income) woman. The specifications with the restrictive sharing rule overestimate the income assignment effects

\footnotetext{
${ }^{41}$ This results is consistent with an entirely different approach, followed by Bloemen (2009).
} 
for women. These restricted rules ignore that the husbands, of which the majority is employed, are more likely to be confronted with a lower virtual non-labour income, which reduces their assignment of income to their wives. It turns out that men are not that bad off, and women are not as well off as initially expected, once this mechanism is taken into account. The flexible sharing rule also shows heterogeneity in the outcomes by marital status. Since married women are on average less often employed and, in the old tax system, more often transfer their tax deductibility to their higher income husband, they are effected more than unmarried women by the tax incentives in terms of increased labour market participation and increased consumption. Their less favourable position in income allocation now works to their advantage, because the marginal effect of the decrease in their husbands' earnings on the income allocation to the wife is smaller. Over all, we find that the most flexible specification, which has both a flexible sharing rule and allows fixed costs, gives the most plausible results. 
Table 1: The Dutch tax system: standard deductible amount and marginal tax rate 1st bracket

\begin{tabular}{|c|c|c|c|}
\hline Year & $\begin{array}{r}\text { transferable } \\
\text { amount }\end{array}$ & $\begin{array}{r}\text { non-transferable } \\
\text { amount }\end{array}$ & $\begin{array}{l}\text { marginal tax } \\
\text { rate } 1 \text { st bracket }\end{array}$ \\
\hline 1990 & 4568 & 0 & $31.5 \%$ \\
\hline 1991 & 4660 & 0 & $35.75 \%$ \\
\hline 1992 & 5225 & 0 & $38.55 \%$ \\
\hline 1993 & 5769 & 0 & $38.4 \%$ \\
\hline 1994 & 5925 & 0 & $38.125 \%$ \\
\hline 1995 & 6074 & 0 & $37.65 \%$ \\
\hline 1996 & 7003 & 0 & $37.5 \%$ \\
\hline 1997 & 7102 & 0 & $37.3 \%$ \\
\hline 1998 & 8207 & 410 & $36.35 \%$ \\
\hline 1999 & 8380 & 419 & $\begin{array}{l}35.75 \% / \\
/ 37.05 \%\end{array}$ \\
\hline 2000 & 8523 & 427 & $\begin{array}{r}33.9 \% / \\
/ 37.95 \% \\
\end{array}$ \\
\hline 2001 & $\begin{array}{r}\text { e deductible } \\
3473\end{array}$ & $\begin{array}{r}\text { labour deductible: } \\
2027\end{array}$ & $\begin{array}{l}32.35 \% / \\
37.60 \% /\end{array}$ \\
\hline \multicolumn{4}{|c|}{$\begin{array}{l}\text { Amounts in Dutch Guilders } \\
\text { Marginal tax rates of the } 2 \text { nd and 3rd bracket: } 50 \% \text { and } 60 \% \\
\text { 1999/2000: first bracket split in two }\end{array}$} \\
\hline
\end{tabular}


Table 2: Bracket bounds for income minus standard deductible

\begin{tabular}{|c|c|c|}
\hline Year & $\begin{aligned} & \text { upper bound } 1 \text { st bracket } \\
= & \text { lower bound } 2 \text { nd bracket }\end{aligned}$ & $\begin{aligned} & \text { upper bound } 2 \text { nd bracket } \\
= & \text { lower bound 3rd bracket }\end{aligned}$ \\
\hline 1990 & 42123 & 84245 \\
\hline 1991 & 42966 & 85930 \\
\hline 1992 & 42966 & 85930 \\
\hline 1993 & 43267 & 86532 \\
\hline 1994 & 43267 & 86532 \\
\hline 1995 & 44349 & 88696 \\
\hline 1996 & 45325 & 92773 \\
\hline 1997 & 45960 & 97422 \\
\hline 1998 & 47184 & 103774 \\
\hline 1999 & $15000 / 48175$ & 105954 \\
\hline 2000 & $15255 / 48994$ & 107756 \\
\hline 2001 & $32769 / 59520$ & 102052 \\
\hline
\end{tabular}


Table 3: descriptive statistics of the pooled data: 8049 observations

\begin{tabular}{|c|c|c|c|}
\hline Variable & Husband & & Wife \\
\hline \multicolumn{4}{|l|}{ Employment status } \\
\hline Employed & $84.5 \%$ & & $70.3 \%$ \\
\hline Not Employed & $15.5 \%$ & & $29.7 \%$ \\
\hline \multicolumn{4}{|l|}{ Education level } \\
\hline Primary & $7.3 \%$ & & $11.2 \%$ \\
\hline Lower vocational & $16.0 \%$ & & $23.4 \%$ \\
\hline Intermediate & $49.3 \%$ & & $42.5 \%$ \\
\hline Higher Vocational & $20.0 \%$ & & $18.2 \%$ \\
\hline University degree & $7.0 \%$ & & $4.4 \%$ \\
\hline \multicolumn{4}{|l|}{ Education sector } \\
\hline Technical & $34.4 \%$ & & $5.3 \%$ \\
\hline Economic/administrative & $25.9 \%$ & & $24.5 \%$ \\
\hline General (not specialized) & $18.1 \%$ & & $30.2 \%$ \\
\hline Services & $21.5 \%$ & & $40.0 \%$ \\
\hline \multicolumn{4}{|l|}{ Weekly working hours } \\
\hline \# Observations & $\mathrm{n}=6618$ & & $\mathrm{n}=5408$ \\
\hline Mean & 39.4 & & 30.9 \\
\hline (Standard deviation) & $(7.9)$ & & $(10.8)$ \\
\hline \multicolumn{4}{|l|}{ Hourly gross wage rates } \\
\hline \# Observations & $\mathrm{n}=6100$ & & $\mathrm{n}=5029$ \\
\hline Mean (Guilders) & 30.2 & & 24.7 \\
\hline (Standard deviation) & $(10.0)$ & & $(8.4)$ \\
\hline \multicolumn{4}{|l|}{ Age } \\
\hline Mean & 40.8 & & 38.7 \\
\hline (Standard deviation) & $(12.4)$ & & $(12.5)$ \\
\hline \multicolumn{4}{|l|}{ Household level variables } \\
\hline \multicolumn{4}{|l|}{ Non-labour income } \\
\hline \multicolumn{4}{|l|}{ Household level, weekly } \\
\hline Mean (guilders) & & 37.7 & \\
\hline \multicolumn{4}{|l|}{ Standard deviation } \\
\hline \multicolumn{4}{|l|}{ Employment status } \\
\hline Both partners working & & $64.3 \%$ & \\
\hline Husband working, wife not & & $20.2 \%$ & \\
\hline Wife working, husband not & & $6.0 \%$ & \\
\hline Both not working & & $9.5 \%$ & \\
\hline \multicolumn{4}{|l|}{ Marital status } \\
\hline Married & & $69.1 \%$ & \\
\hline
\end{tabular}


Table 4: Estimates of the utility parameters

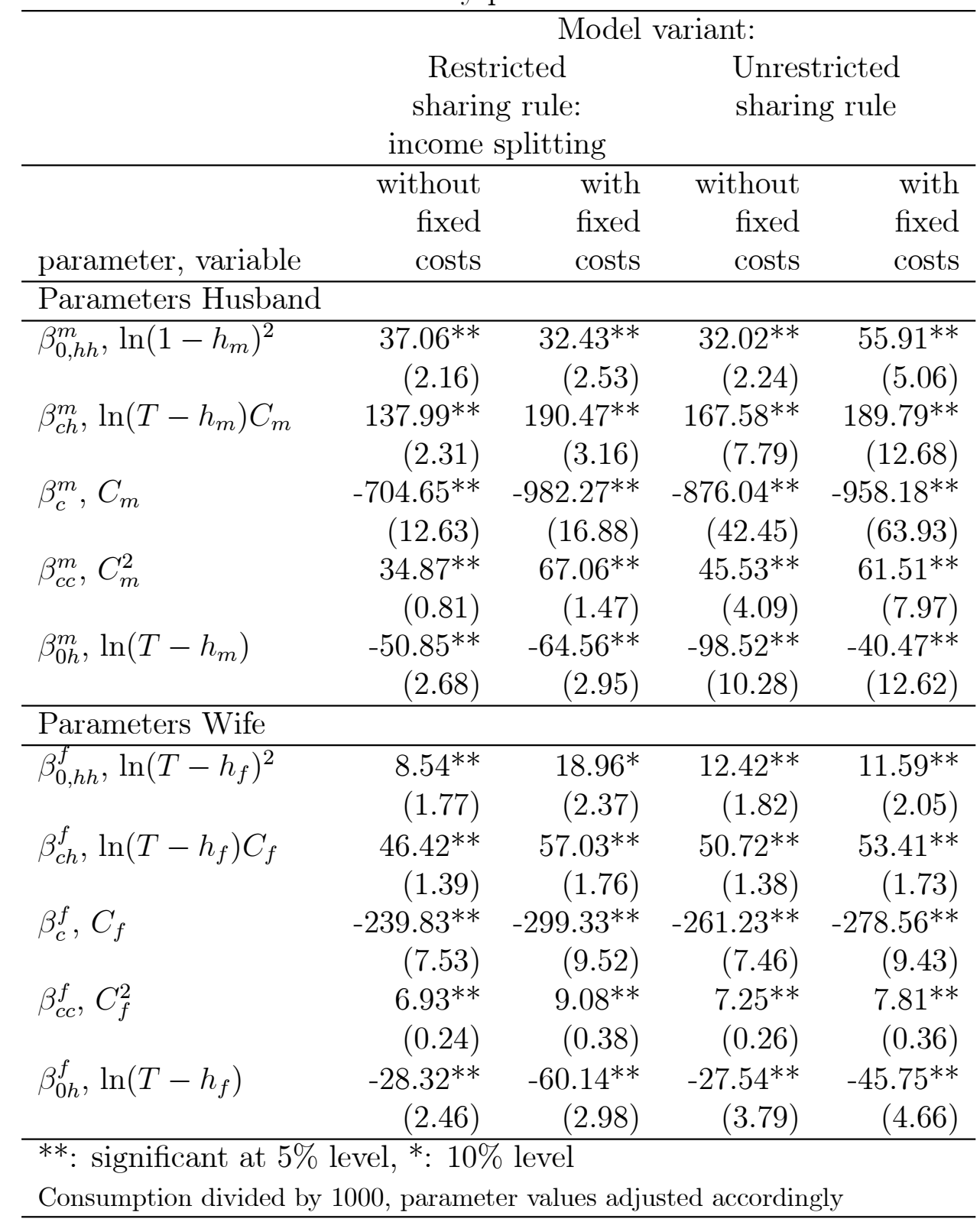


Table 5: Estimates of the fixed costs parameters

\begin{tabular}{|c|c|c|}
\hline \multirow[b]{2}{*}{ parameter, variable } & \multicolumn{2}{|c|}{ Model variant: } \\
\hline & $\begin{array}{c}\text { Restricted } \\
\text { sharing rule: } \\
\text { income splitting }\end{array}$ & $\begin{array}{l}\text { Unrestricted } \\
\text { sharing rule }\end{array}$ \\
\hline \multicolumn{3}{|l|}{ Parameters Husband } \\
\hline$F_{m}$, Fixed Cost, intercept & $\begin{array}{r}142.21^{* *} \\
(21.80)\end{array}$ & $\begin{array}{r}-244.54^{* *} \\
(45.52)\end{array}$ \\
\hline$F_{m}, \ln ($ age husband $/ 17)$ & $\begin{array}{r}-590.50^{* *} \\
(60.84)\end{array}$ & $\begin{array}{r}463.47^{* *} \\
(80.54)\end{array}$ \\
\hline$F_{m}, \ln (\text { age husband } / 17)^{2}$ & $\begin{array}{r}564.12^{* *} \\
(35.70)\end{array}$ & $\begin{array}{r}-47.79 \\
(44.93)\end{array}$ \\
\hline$F_{m}$, marital status & $\begin{array}{r}-39.52^{* *} \\
(8.65)\end{array}$ & $\begin{array}{r}18.93 \\
(18.79) \\
\end{array}$ \\
\hline \multicolumn{3}{|l|}{ Parameters Wife } \\
\hline$F_{f}$, Fixed Cost, intercept & $\begin{array}{r}-556.89^{* *} \\
(60.66)\end{array}$ & $\begin{array}{r}-204.99^{* *} \\
(60.90)\end{array}$ \\
\hline$F_{f}, \ln ($ age wife $/ 17)$ & $\begin{array}{r}696.99^{* *} \\
(166.63)\end{array}$ & $\begin{array}{r}-236.71 \\
(177.23)\end{array}$ \\
\hline$F_{f}, \ln (\text { age wife } / 17)^{2}$ & $\begin{array}{r}-117.74 \\
(100.71)\end{array}$ & $\begin{array}{r}438.98^{* *} \\
(111.93)\end{array}$ \\
\hline$F_{f}$, marital status & $\begin{array}{r}22.29 \\
(25.83)\end{array}$ & $\begin{array}{l}-29.31 \\
(26.96)\end{array}$ \\
\hline $\begin{array}{l}* * \text { : significant at } 5 \% \text { level, } \\
\text { Fixed costs in units of } 1000 \mathrm{Gl}\end{array}$ & $\begin{array}{l}*: 10 \% \text { level } \\
\text { lders }\end{array}$ & \\
\hline
\end{tabular}


Table 6: Estimates of the sharing rule

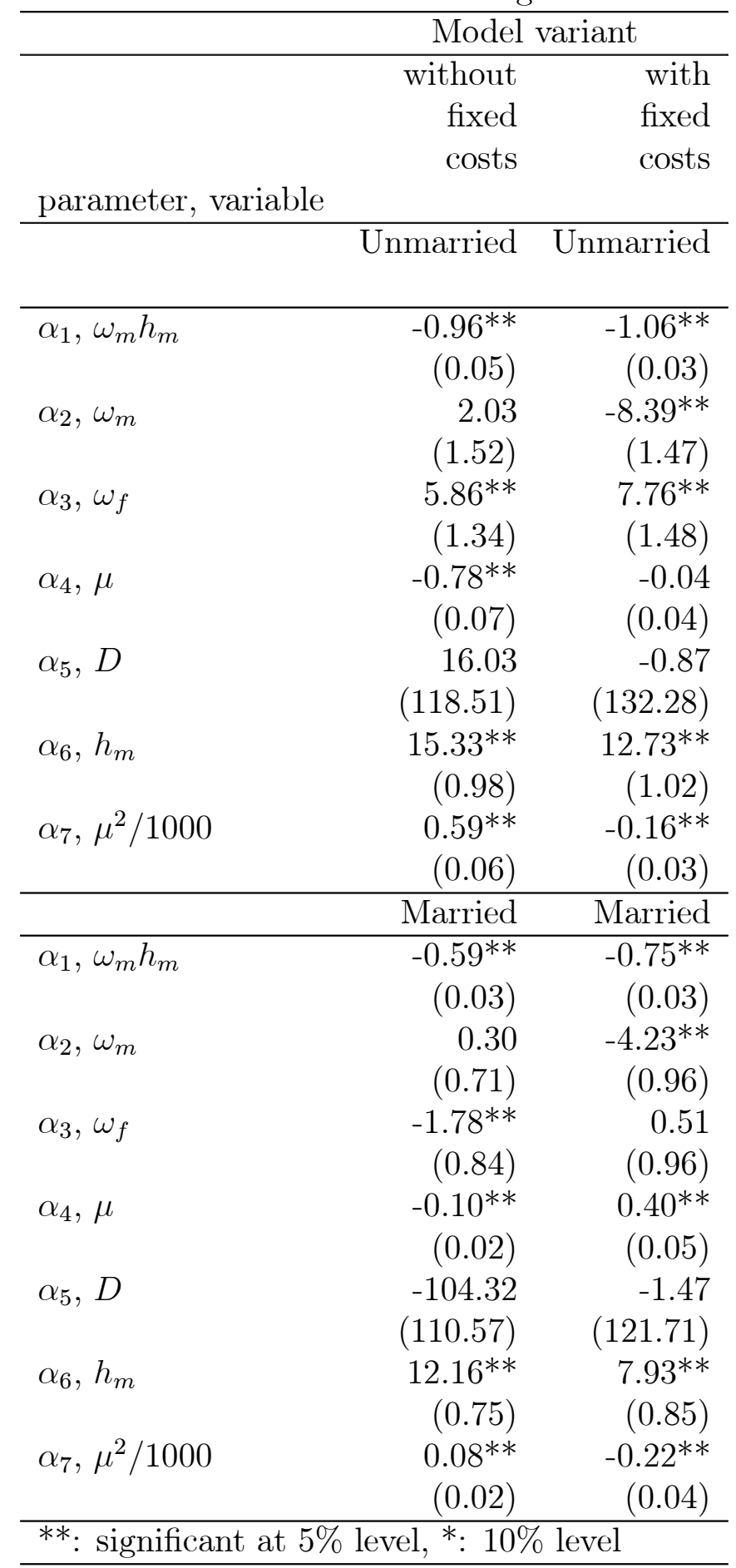


Table 7a: Estimates of the 'structural model' The taste shifters, husband: parameters $\beta_{h h}^{m}$

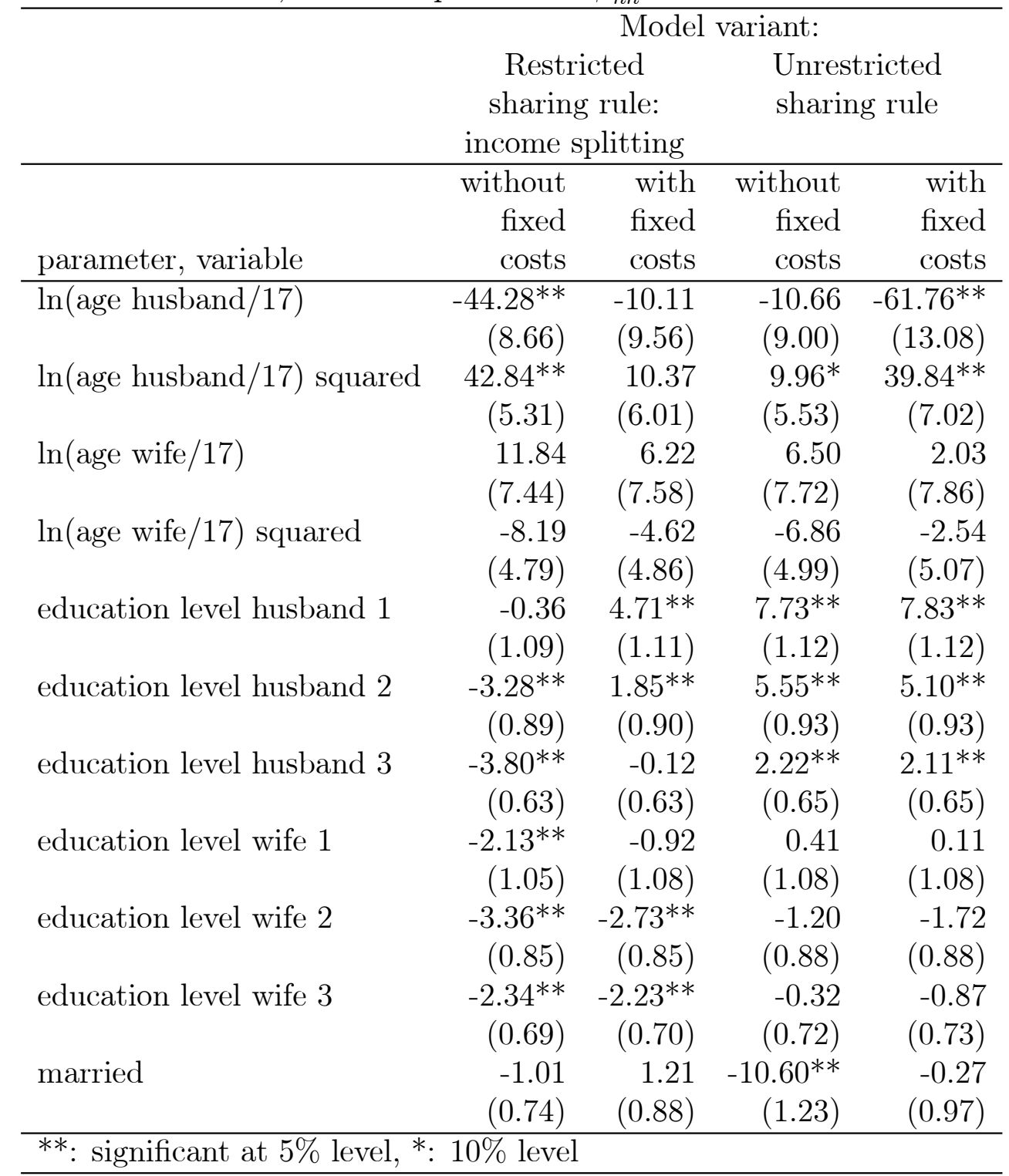


Table 7b: Estimates of the 'structural model' parameters The taste shifters husband: parameters $\beta_{h}^{m}$

\begin{tabular}{|c|c|c|c|c|}
\hline & \multicolumn{4}{|c|}{ Model variant: } \\
\hline & \multicolumn{2}{|c|}{$\begin{array}{c}\text { Restricted } \\
\text { sharing rule: } \\
\text { income splitting }\end{array}$} & \multicolumn{2}{|c|}{$\begin{array}{l}\text { Unrestricted } \\
\text { sharing rule }\end{array}$} \\
\hline & without & with & without & with \\
\hline & fixed & fixed & fixed & fixed \\
\hline parameter, variable & costs & costs & costs & costs \\
\hline $\ln ($ age husband/17) & $\begin{array}{r}-34.72^{* *} \\
(7.30)\end{array}$ & $\begin{array}{r}-51.80^{* *} \\
(7.79)\end{array}$ & $\begin{array}{r}-47.94^{* *} \\
(7.40)\end{array}$ & $\begin{array}{r}-44.27^{* *} \\
(8.37)\end{array}$ \\
\hline $\ln ($ age husband/17) squared & $\begin{array}{r}13.07^{* *} \\
(4.63)\end{array}$ & $\begin{array}{r}32.76^{* *} \\
(4.90)\end{array}$ & $\begin{array}{r}31.41^{* *} \\
(4.66)\end{array}$ & $\begin{array}{r}23.60^{* *} \\
(4.98)\end{array}$ \\
\hline $\ln ($ age wife/17) & $\begin{array}{r}-12.80^{* *} \\
(6.10)\end{array}$ & $\begin{array}{l}-3.93 \\
(6.40)\end{array}$ & $\begin{array}{r}0.06 \\
(6.32)\end{array}$ & $\begin{array}{r}4.26 \\
(6.45)\end{array}$ \\
\hline $\ln ($ age wife/17) squared & $\begin{array}{r}10.14^{* *} \\
(4.04)\end{array}$ & $\begin{array}{r}4.84 \\
(4.22)\end{array}$ & $\begin{array}{r}2.21 \\
(4.17)\end{array}$ & $\begin{array}{r}0.12 \\
(4.29)\end{array}$ \\
\hline education level husband 1 & $\begin{array}{r}4.03^{* *} \\
(1.00)\end{array}$ & $\begin{array}{r}0.12 \\
(1.02)\end{array}$ & $\begin{array}{l}-1.76^{*} \\
(1.00)\end{array}$ & $\begin{array}{r}-1.44 \\
(1.03)\end{array}$ \\
\hline education level husband 2 & $\begin{array}{l}4.08^{* *} \\
(0.81)\end{array}$ & $\begin{array}{r}0.34 \\
(0.82)\end{array}$ & $\begin{array}{r}-2.27^{* *} \\
(0.79)\end{array}$ & $\begin{array}{r}-1.69^{* *} \\
(0.80)\end{array}$ \\
\hline education level husband 3 & $\begin{array}{r}2.83^{* *} \\
(0.54)\end{array}$ & $\begin{array}{l}-0.20 \\
(0.55)\end{array}$ & $\begin{array}{r}-1.12^{* *} \\
(0.53)\end{array}$ & $\begin{array}{r}-0.58 \\
(0.54)\end{array}$ \\
\hline education level wife 1 & $\begin{array}{l}4.08^{* *} \\
(0.94)\end{array}$ & $\begin{array}{r}2.72^{* *} \\
(0.96)\end{array}$ & $\begin{array}{r}2.04^{* *} \\
(0.96)\end{array}$ & $\begin{array}{r}1.81 \\
(0.97)\end{array}$ \\
\hline education level wife 2 & $\begin{array}{r}3.07^{* *} \\
(0.71)\end{array}$ & $\begin{array}{r}1.99 * * \\
(0.72)\end{array}$ & $\begin{array}{l}1.28^{*} \\
(0.72)\end{array}$ & $\begin{array}{r}1.06 \\
(0.73)\end{array}$ \\
\hline education level wife 3 & $\begin{array}{r}1.71^{* *} \\
(0.55)\end{array}$ & $\begin{array}{r}0.88 \\
(0.56)\end{array}$ & $\begin{array}{r}0.00 \\
(0.56)\end{array}$ & $\begin{array}{r}-0.24 \\
(0.57)\end{array}$ \\
\hline married & $\begin{array}{r}0.76 \\
(0.58)\end{array}$ & $\begin{array}{r}-1.61^{* *} \\
(0.67)\end{array}$ & $\begin{array}{r}-2.10^{* *} \\
(0.77)\end{array}$ & $\begin{array}{r}0.27 \\
(0.93)\end{array}$ \\
\hline
\end{tabular}


Table 7c: Estimates of the 'structural model' The taste shifters, wife: parameters $\beta_{h h}^{f}$

\begin{tabular}{lrrrr}
\hline & \multicolumn{2}{c}{ Model variant: } \\
& Restricted & Unrestricted \\
sharing rule: & sharing rule \\
& income splitting & & \\
\hline & without & with & without & with \\
& fixed & fixed & fixed & fixed \\
parameter, variable & costs & costs & costs & costs \\
\hline ln(age husband/17) & $19.82^{* *}$ & $30.08^{* *}$ & $19.60^{* *}$ & $31.08^{* *}$ \\
& $(6.92)$ & $(6.94)$ & $(7.09)$ & $(6.85)$ \\
$\ln ($ age husband/17) squared & $-13.11^{* *}$ & $-18.00^{* *}$ & $-11.95^{* *}$ & $-17.57^{* *}$ \\
& $(4.19)$ & $(4.17)$ & $(4.32)$ & $(4.12)$ \\
ln(age wife/17) & -7.04 & $-30.61^{* *}$ & $-15.54^{* *}$ & -9.54 \\
& $(5.61)$ & $(6.97)$ & $(5.79)$ & $(6.51)$ \\
$\ln ($ age wife/17) squared & 7.73 & $16.03^{* *}$ & $12.13^{* *}$ & 2.81 \\
& $(3.63)$ & $(4.19)$ & $(3.79)$ & $(4.22)$ \\
education level husband 1 & $-3.00^{* *}$ & $-2.74^{* *}$ & $-2.67^{* *}$ & $-3.28^{* *}$ \\
& $(0.76)$ & $(0.76)$ & $(0.79)$ & $(0.80)$ \\
education level husband 2 & $-1.60^{* *}$ & $-1.77^{* *}$ & $-1.76^{* *}$ & $-2.45^{* *}$ \\
& $(0.63)$ & $(0.62)$ & $(0.65)$ & $(0.65)$ \\
education level husband 3 & $-1.57^{* *}$ & $-1.57^{* *}$ & -1.75 & $-2.13^{* *}$ \\
& $(0.49)$ & $(0.48)$ & $(0.50)$ & $(0.50)$ \\
education level wife 1 & -0.67 & -0.15 & -0.71 & -0.39 \\
& $(0.77)$ & $(0.75)$ & $(0.80)$ & $(0.76)$ \\
education level wife 2 & 0.04 & 0.13 & -0.27 & -0.24 \\
& $(0.64)$ & $(0.62)$ & $(0.66)$ & $(0.63)$ \\
education level wife 3 & $-1.41^{* *}$ & $-1.25^{* *}$ & $-1.80^{* *}$ & $-1.58^{* *}$ \\
& $(0.56)$ & $(0.54)$ & $(0.57)$ & $(0.55)$ \\
married & 0.29 & -0.49 & -0.19 & -0.46 \\
& $(0.59)$ & $(0.80)$ & $(0.60)$ & $(0.79)$ \\
\hline **: significant at 5\% level, *: $10 \%$ level & & & \\
\hline & & & &
\end{tabular}


Table 7d: Estimates of the 'structural model' parameters The taste shifters, wife: parameters $\beta_{h}^{f}$

\begin{tabular}{|c|c|c|c|c|}
\hline & \multicolumn{4}{|c|}{ Model variant: } \\
\hline & \multicolumn{2}{|c|}{$\begin{array}{c}\text { Restricted } \\
\text { sharing rule: } \\
\text { income splitting }\end{array}$} & \multicolumn{2}{|c|}{$\begin{array}{l}\text { Unrestricted } \\
\text { sharing rule }\end{array}$} \\
\hline & without & with & without & with \\
\hline & fixed & fixed & fixed & fixed \\
\hline \multirow{3}{*}{$\frac{\text { parameter, variable }}{\ln (\text { age husband } / 17)}$} & costs & costs & costs & costs \\
\hline & $-25.88^{* *}$ & $-28.20^{* *}$ & $-29.50^{* *}$ & $-33.85^{* *}$ \\
\hline & $(6.91)$ & $(6.91)$ & $(6.86)$ & $(6.88)$ \\
\hline \multirow[t]{2}{*}{$\ln ($ age husband/17) squared } & $17.13^{* *}$ & $18.43^{* *}$ & $18.48^{* *}$ & $21.34^{* *}$ \\
\hline & $(4.32)$ & $(4.34)$ & $(4.34)$ & $(4.34)$ \\
\hline \multirow[t]{2}{*}{$\ln ($ age wife/17) } & $-45.68 * *$ & $-15.37 * *$ & $-49.47^{* *}$ & $-36.38 * *$ \\
\hline & $(5.69)$ & $(6.21)$ & $(5.81)$ & $(6.20)$ \\
\hline \multirow[t]{2}{*}{$\ln ($ age wife/17) squared } & $41.47^{* *}$ & $24.52^{* *}$ & $45.62^{* *}$ & $38.99^{* *}$ \\
\hline & $(3.81)$ & $(4.05)$ & $(3.90)$ & $(4.11)$ \\
\hline \multirow[t]{2}{*}{ education level husband 1} & $7.00^{* *}$ & $6.17^{* *}$ & $6.98^{* *}$ & $6.77^{* *}$ \\
\hline & $(1.07)$ & $(1.09)$ & $(1.11)$ & $(1.12)$ \\
\hline \multirow[t]{2}{*}{ education level husband 2} & $2.23^{* *}$ & $1.98^{* *}$ & $2.66^{* *}$ & $2.63^{* *}$ \\
\hline & $(0.71)$ & $(0.71)$ & $(0.71)$ & $(0.72)$ \\
\hline \multirow[t]{2}{*}{ education level husband 3} & $1.47^{* *}$ & $1.31^{* *}$ & $1.70^{* *}$ & $1.74^{* *}$ \\
\hline & $(0.54)$ & $(0.53)$ & $(0.54)$ & $(0.55)$ \\
\hline \multirow[t]{2}{*}{ education level wife 1} & $7.39^{* *}$ & $7.03^{* *}$ & $7.42^{* *}$ & $6.81^{* *}$ \\
\hline & $(0.93)$ & $(0.95)$ & $(0.95)$ & $(0.95)$ \\
\hline \multirow[t]{2}{*}{ education level wife 2} & $3.78^{* *}$ & $4.18^{* *}$ & $4.14^{* *}$ & $3.79^{* *}$ \\
\hline & $(0.70)$ & $(0.70)$ & $(0.71)$ & $(0.71)$ \\
\hline \multirow[t]{2}{*}{ education level wife 3} & $2.74^{* *}$ & $3.10^{* *}$ & $3.11^{* *}$ & $2.74^{* *}$ \\
\hline & $(0.58)$ & $(0.57)$ & $(0.58)$ & $(0.59)$ \\
\hline \multirow[t]{2}{*}{ married } & $1.83^{* *}$ & $2.46^{* *}$ & $2.77 * *$ & $2.07^{* *}$ \\
\hline & $(0.54)$ & $(0.68)$ & $(0.58)$ & $(0.68)$ \\
\hline
\end{tabular}


Table 8: Elasticities of working hours and participation

\begin{tabular}{|c|c|c|c|c|}
\hline & \multicolumn{4}{|c|}{ Model variant: } \\
\hline & \multicolumn{2}{|c|}{$\begin{array}{c}\text { Restricted } \\
\text { sharing rule: } \\
\text { income splitting }\end{array}$} & \multicolumn{2}{|c|}{$\begin{array}{l}\text { Unrestricted } \\
\text { sharing rule }\end{array}$} \\
\hline & $\begin{array}{r}\text { without } \\
\text { fixed } \\
\text { costs }\end{array}$ & $\begin{array}{l}\text { with } \\
\text { fixed } \\
\text { costs }\end{array}$ & $\begin{array}{r}\text { without } \\
\text { fixed } \\
\text { costs }\end{array}$ & $\begin{array}{l}\text { with } \\
\text { fixed } \\
\text { costs }\end{array}$ \\
\hline $\begin{array}{l}\text { Working hours husband: } \\
\text { wage rate husband }\end{array}$ & $\begin{array}{r}0.045 \\
(0.056)\end{array}$ & $\begin{array}{r}-0.025 \\
(0.049)\end{array}$ & $\begin{array}{r}0.071^{* *} \\
(0.028)\end{array}$ & $\begin{array}{r}0.002 \\
(0.048)\end{array}$ \\
\hline wage rate wife & $\begin{array}{r}-0.090^{* *} \\
(0.005)\end{array}$ & $\begin{array}{r}-0.053^{* *} \\
(0.003)\end{array}$ & $\begin{array}{r}-0.112^{* *} \\
(0.023)\end{array}$ & $\begin{array}{r}0.006 \\
(0.015)\end{array}$ \\
\hline non-labour income & $\begin{array}{r}-0.013^{* *} \\
(0.001)\end{array}$ & $\begin{array}{r}-0.006^{* *} \\
(0.001)\end{array}$ & $\begin{array}{r}-0.007^{* *} \\
(0.002)\end{array}$ & $\begin{array}{r}-0.001 \\
(0.002)\end{array}$ \\
\hline $\begin{array}{l}\text { Participation husband: } \\
\text { wage rate husband }\end{array}$ & $\begin{array}{r}0.301^{* *} \\
(0.044)\end{array}$ & $\begin{array}{r}0.029 \\
(0.039)\end{array}$ & $\begin{array}{r}0.028 \\
(0.026)\end{array}$ & $\begin{array}{r}-0.017 \\
(0.038)\end{array}$ \\
\hline wage rate wife & $\begin{array}{r}-0.034^{* *} \\
(0.005)\end{array}$ & $\begin{array}{r}-0.022^{* *} \\
(0.002)\end{array}$ & $\begin{array}{r}-0.104^{* *} \\
(0.023)\end{array}$ & $\begin{array}{r}-0.002 \\
(0.012)\end{array}$ \\
\hline non-labour income & $\begin{array}{r}-0.003^{* *} \\
(0.001) \\
\end{array}$ & $\begin{array}{r}-0.002^{*} \\
(0.001) \\
\end{array}$ & $\begin{array}{r}-0.007^{* *} \\
(0.002) \\
\end{array}$ & $\begin{array}{r}-0.002 \\
(0.002)\end{array}$ \\
\hline $\begin{array}{l}\text { Working hours wife: } \\
\text { wage rate husband }\end{array}$ & $\begin{array}{r}-0.033 \\
(0.039)\end{array}$ & $\begin{array}{r}-0.026 \\
(0.035)\end{array}$ & $\begin{array}{r}-0.150^{* *} \\
(0.028)\end{array}$ & $\begin{array}{r}-0.056 \\
(0.038)\end{array}$ \\
\hline wage rate wife & $\begin{array}{r}0.248^{* *} \\
(0.042)\end{array}$ & $\begin{array}{r}0.036 \\
(0.045)\end{array}$ & $\begin{array}{r}0.230^{* *} \\
(0.057)\end{array}$ & $\begin{array}{r}0.256^{* *} \\
(0.056)\end{array}$ \\
\hline non-labour income & $\begin{array}{r}-0.002 \\
(0.007)\end{array}$ & $\begin{array}{r}0.001 \\
(0.007) \\
\end{array}$ & $\begin{array}{r}-0.008 \\
(0.005)\end{array}$ & $\begin{array}{r}0.002 \\
(0.005)\end{array}$ \\
\hline $\begin{array}{l}\text { Participation wife: } \\
\text { wage rate husband }\end{array}$ & $\begin{array}{r}0.067^{* * *} \\
(0.036)\end{array}$ & $\begin{array}{r}0.076^{* *} \\
(0.031)\end{array}$ & $\begin{array}{r}0.005 \\
(0.025)\end{array}$ & $\begin{array}{r}0.107^{* *} \\
(0.038)\end{array}$ \\
\hline wage rate wife & $\begin{array}{r}0.377^{* *} \\
(0.033)\end{array}$ & $\begin{array}{r}0.144^{* *} \\
(0.037)\end{array}$ & $\begin{array}{r}0.377^{* *} \\
(0.043)\end{array}$ & $\begin{array}{r}0.309^{* *} \\
(0.041)\end{array}$ \\
\hline non-labour income & $\begin{array}{r}0.003 \\
(0.006)\end{array}$ & $\begin{array}{r}0.005 \\
(0.006)\end{array}$ & $\begin{array}{r}0.002 \\
(0.005)\end{array}$ & $\begin{array}{r}0.008^{*} \\
(0.004)\end{array}$ \\
\hline
\end{tabular}


Table 9a: Effects of changes in wage rates and non-labour income on consumption, the sharing rule, and utility

Restricted sharing rule

\begin{tabular}{|c|c|c|c|}
\hline \multicolumn{4}{|c|}{ Variant: Restricted sharing rule, no fixed costs } \\
\hline percentage & $1 \%$ increase & $1 \%$ increase & 1 guilder \\
\hline with & gross wage & gross wage & increase \\
\hline increase & rate husband & rate wife & non-labour \\
\hline & & & income \\
\hline \multicolumn{4}{|c|}{ unmarried subsample } \\
\hline consumption husband & 99.6 & 29.3 & 99.5 \\
\hline consumption & 86.2 & 91.7 & 66.9 \\
\hline share (husba & 11.2 & 27.0 & 100.0 \\
\hline \multicolumn{4}{|c|}{ married subsample } \\
\hline consumption husband & 100.0 & 47.9 & $\overline{99.9}$ \\
\hline consumption wife & 95.2 & 93.5 & 82.5 \\
\hline share (husband) & 12.9 & 67.4 & 99.6 \\
\hline \multicolumn{4}{|c|}{ Variant: Restricted sharing rule, fixed costs } \\
\hline percentage & $1 \%$ increase & $1 \%$ increase & 1 guilder \\
\hline with & gross wage & gross wage & increase \\
\hline positive & rate husband & rate wife & non-labour \\
\hline change in: & & & income \\
\hline \multicolumn{4}{|c|}{ unmarried subsample } \\
\hline consumption & 98.3 & 39.5 & $\overline{99.9}$ \\
\hline consumption & 95.4 & 96.8 & 79.1 \\
\hline share (husba & 26.4 & 55.5 & 100.0 \\
\hline \multicolumn{4}{|c|}{ married subsample } \\
\hline consumption husband & 90.5 & 41.9 & 99.9 \\
\hline cons & 85.2 & 92.4 & 86.7 \\
\hline share (husband) & 35.8 & 63.6 & 99.0 \\
\hline
\end{tabular}


Table 9b: Effects of changes in wage rates and non-labour income on consumption, the sharing rule, and utility

Flexible sharing rule

\begin{tabular}{|c|c|c|c|}
\hline \multicolumn{4}{|c|}{ Variant: Flexible sharing rule, no fixed costs } \\
\hline percentage & $1 \%$ increase & $1 \%$ increase & 1 guilder \\
\hline with & gross wage & gross wage & increase \\
\hline $\begin{array}{l}\text { increase } \\
\text { in: }\end{array}$ & rate husband & rate wife & $\begin{array}{r}\text { non-labour } \\
\text { income }\end{array}$ \\
\hline \multicolumn{4}{|c|}{ unmarried subsample } \\
\hline consumption husband & 87.4 & 84.9 & 1.5 \\
\hline consumption & 99.5 & 95.8 & 99.7 \\
\hline share (husbar & 5.5 & 90.7 & 1.5 \\
\hline \multicolumn{4}{|c|}{ married subsample } \\
\hline consumption husband & 88.7 & 10.8 & $\overline{1.2}$ \\
\hline consumption wife & 97.7 & 99.8 & 99.4 \\
\hline share (husband) & 9.1 & 22.6 & 11.7 \\
\hline \multicolumn{4}{|c|}{ Variant: Flexible sharing rule, fixed costs } \\
\hline percentage & $1 \%$ increase & $1 \%$ increase & 1 guilder \\
\hline with & gross wage & gross wage & increase \\
\hline positive & rate husband & rate wife & non-labour \\
\hline change in: & & & income \\
\hline \multicolumn{4}{|c|}{ unmarried subsample } \\
\hline consumption husband & 3.8 & 72.3 & 0.8 \\
\hline consumption wife & 100.0 & 97.8 & 99.7 \\
\hline share (husband) & 8.4 & 76.9 & 0.1 \\
\hline \multicolumn{4}{|c|}{ married subsample } \\
\hline consumption husband & 75.4 & 81.6 & 98.6 \\
\hline ption wife & 100.0 & 100.0 & 99.0 \\
\hline share (husband) & 13.4 & 92.8 & 97.9 \\
\hline
\end{tabular}


Table 10: Changing the tax policy Implications for sharing

\begin{tabular}{lrrrr}
\hline & \multicolumn{3}{c}{ Model variant: } \\
& $\begin{array}{l}\text { Restricted } \\
\text { sharing rule: }\end{array}$ & Unrestricted \\
& sharing rule \\
& income splitting & & \\
\hline Percentage & without & with & without & with \\
with & fixed & fixed & fixed & fixed \\
increase in: & costs & costs & costs & costs \\
\hline \multicolumn{5}{c}{ unmarried subsample } \\
\hline consumption husband & 18.5 & 17.9 & 99.2 & 56.0 \\
consumption wife & 99.8 & 99.9 & 13.5 & 57.1 \\
share husband & 0.0 & 0.0 & 27.6 & 0.2 \\
share wife & 18.5 & 19.5 & 2.9 & 6.7 \\
\hline \multicolumn{5}{c}{ married subsample } \\
\hline consumption husband & 45.8 & 37.5 & 100.0 & 12.1 \\
consumption wife & 100.0 & 99.5 & 56.9 & 95.8 \\
share husband & 0.0 & 0.0 & 0.0 & 0.0 \\
share wife & 45.8 & 51.3 & 12.5 & 50.9 \\
\hline
\end{tabular}

Table 11: Changing the tax policy

Implications for working hours and participation

\begin{tabular}{|c|c|c|c|c|}
\hline & \multicolumn{4}{|c|}{ Model variant: } \\
\hline & \multicolumn{2}{|c|}{$\begin{array}{c}\text { Restricted } \\
\text { sharing rule: } \\
\text { income splitting }\end{array}$} & \multicolumn{2}{|c|}{$\begin{array}{l}\text { Unrestricted } \\
\text { sharing rule }\end{array}$} \\
\hline \multirow[t]{2}{*}{ Change in: } & $\begin{array}{r}\text { without } \\
\text { fixed } \\
\text { costs }\end{array}$ & $\begin{array}{l}\text { with } \\
\text { fixed } \\
\text { costs }\end{array}$ & $\begin{array}{r}\text { without } \\
\text { fixed } \\
\text { costs }\end{array}$ & $\begin{array}{l}\text { with } \\
\text { fixed } \\
\text { costs }\end{array}$ \\
\hline & \multicolumn{4}{|c|}{ unmarried subsample } \\
\hline working hours husband & 1.3 & 0.9 & 0.1 & -0.1 \\
\hline working hours wife & 0.4 & 0.5 & 1.0 & 0.4 \\
\hline participation husband & 2.3 & 1.0 & 1.3 & 0.8 \\
\hline participation wife & 1.6 & 1.1 & 1.2 & 0.5 \\
\hline \multicolumn{5}{|c|}{ married subsample } \\
\hline working hours husband & 1.1 & 1.0 & 2.2 & 0.0 \\
\hline working hours wife & 2.1 & 1.5 & 1.7 & 1.6 \\
\hline participation husband & 1.4 & 1.5 & 3.8 & -0.1 \\
\hline participation wife & 6.4 & 4.6 & 4.7 & 5.1 \\
\hline \multicolumn{5}{|c|}{$\begin{array}{l}\text { Working hours: change in average number per week } \\
\text { Participation: change in percentage points }\end{array}$} \\
\hline
\end{tabular}




\section{A The wage equation}

The parameters estimates of the wage equations in (13) are obtained in a first step. The parameters of the wage equation are estimated simultaneously with a selection equation for the labour market state. Let $d_{j}$ be an indicator taking the value 1 if household member $j$ is employed and taking the value 0 if not. The selection equation is

$$
\begin{aligned}
& d_{j}^{*}=m_{j}^{\prime} \theta_{j}+l_{j}, j=m, f \\
& d_{j}=\iota\left(d_{j}^{*}>0\right)
\end{aligned}
$$

The error terms of the wage equation (13) and the selection equation (30) is assumed to be distributed according to the bivariate normal distribution:

$$
\left(\begin{array}{c}
l_{j} \\
v_{j}
\end{array}\right) \sim N\left(\left(\begin{array}{l}
0 \\
0
\end{array}\right),\left(\begin{array}{cc}
1 & \rho_{v l, j} \tau_{j} \\
\rho_{v l, j} \tau_{j} & \tau_{j}^{2}
\end{array}\right)\right), j=m, f
$$

in which $\rho_{v l, j}$ represents the correlation coefficient between the error term of the wage equation $v_{j}$ and the error in the selection equation $l_{j}$. The parameters $\eta_{j}, \theta_{j}, \rho_{l v, j}$, and $\tau_{j}$ are estimated simultaneously by maximum likelihood.

Table A.1 contains the maximum-likelihood estimates of the parameters of the participation equation and table A.2 contains the estimates of the wage equations of both

husband and wife. In the wage equation we included a quadratic in the individual's age, dummy variables for the level of education, dummy variables for the type, or sector, of education, and time dummies. Note that the selection equation may be interpreted as an approximation of the 'reduced form' employment equation that follows from the structural model. In the employment equation we include all the variables that appear as taste shifters in the utility function, which are the age of both partners, the level of education of both partners, and the marital status. Since the participation decision also depends on the wage of the partner, we also include the sector dummies of the partner in the employment equation. Because of the 'reduced form' nature of the selection equation it is hard to interpret the values of the estimates, and we do not devote much time discussing them. Nevertheless we may point at some interesting interactions of the partner's education on the employment status. We see that men with the lowest level of education have a lower probability of being employment, and we see that men with wives who have any of the middle three education levels have a higher probability of 
being employed than men whose wives have either the lowest education level or university level. For the female employment status we do not find a significant impact of the husband's level of education, but we do see that her probability of being in employment increases monotonically with her own level of education. Since the employment equation is reduced form, we do not know whether this increasing pattern is due to the wage or due to preferences. The correlation coefficient for the correlation between the errors of the employment and wage equation are significant for both husband and wife, showing the relevance of incorporating selectivity in the estimation of the parameters of the wage equation.

Table A.2 shows the estimates of the wage equations. Both the wage equation of the husband and of the wife show an increasing pattern in the level of education, and both men and women with an economic/administrative or a general type of education have higher wages than men and women working in technical or service sector. 
Table A1: ML Estimates of the employment equations

\begin{tabular}{|c|c|c|c|c|}
\hline \multirow[b]{2}{*}{ Variable } & \multicolumn{2}{|c|}{ Husband } & \multicolumn{2}{|c|}{ Wife } \\
\hline & estimate & std. err. & estimate & std. err. \\
\hline intercept & -0.247 & 0.230 & 1.294 & 0.202 \\
\hline log(age husband/17) & 5.748 & 0.616 & -0.877 & 0.522 \\
\hline $\log$ (age husb./17) squared & -4.049 & 0.385 & 0.477 & 0.323 \\
\hline $\log ($ age wife/17) & -0.927 & 0.496 & 3.261 & 0.459 \\
\hline $\log ($ age wife/17) squared & 0.418 & 0.333 & -2.975 & 0.303 \\
\hline Education level husband 1 & -0.665 & 0.141 & -0.439 & 0.096 \\
\hline Education level husband 2 & -0.255 & 0.117 & -0.279 & 0.078 \\
\hline Education level husband 3 & -0.081 & 0.109 & -0.213 & 0.072 \\
\hline Education level husband 4 & -0.024 & 0.112 & -0.178 & 0.073 \\
\hline Education level wife 1 & -0.131 & 0.115 & -0.683 & 0.130 \\
\hline Education level wife 2 & 0.206 & 0.106 & -0.541 & 0.119 \\
\hline Education level wife 3 & 0.331 & 0.104 & -0.324 & 0.115 \\
\hline Education level wife 4 & 0.230 & 0.106 & -0.223 & 0.119 \\
\hline Married & 0.090 & 0.048 & -0.114 & 0.047 \\
\hline Sector Technical husband & -0.026 & 0.055 & 0.002 & 0.040 \\
\hline Sector Econ./adm. husband & 0.034 & 0.061 & 0.035 & 0.056 \\
\hline Sector General husband & 0.062 & 0.076 & -0.144 & 0.089 \\
\hline
\end{tabular}


Table A1: ML Estimates of the employment equations (ctd.)

\begin{tabular}{|c|c|c|c|c|}
\hline \multirow[b]{2}{*}{ Variable } & \multicolumn{2}{|c|}{ Husband } & \multicolumn{2}{|c|}{ Wife } \\
\hline & estimate & std. err. & estimate & std. err. \\
\hline Sector Technical wife & -0.102 & 0.064 & 0.062 & 0.050 \\
\hline Sector Econ./adm. wife & -0.013 & 0.048 & -0.043 & 0.047 \\
\hline Sector General wife & 0.097 & 0.049 & -0.220 & 0.325 \\
\hline$\mu / 1000$ & -0.186 & 0.321 & 0.771 & 0.527 \\
\hline$(\mu / 1000)^{2}$ & 0.149 & 0.424 & -0.343 & 0.082 \\
\hline 1990 & -0.343 & 0.105 & -0.364 & 0.086 \\
\hline 1991 & -0.144 & 0.106 & -0.317 & 0.086 \\
\hline 1992 & -0.207 & 0.105 & -0.299 & 0.087 \\
\hline 1993 & -0.235 & 0.105 & -0.272 & 0.083 \\
\hline 1994 & -0.210 & 0.103 & -0.197 & 0.085 \\
\hline 1995 & -0.061 & 0.108 & -0.188 & 0.082 \\
\hline 1996 & -0.112 & 0.104 & -0.142 & 0.084 \\
\hline 1997 & -0.073 & 0.104 & -0.095 & 0.085 \\
\hline 1998 & -0.119 & 0.106 & -0.182 & 0.085 \\
\hline 1999 & -0.106 & 0.107 & -0.147 & 0.088 \\
\hline 2000 & -0.066 & 0.105 & $-0.17^{*}$ & 0.09 \\
\hline$\rho_{v l, m}$ & -0.953 & 0.007 & - & - \\
\hline$\rho_{v l, f}$ & - & - & -0.935 & 0.006 \\
\hline
\end{tabular}


Table A2: ML Estimates of the Wage equations

\begin{tabular}{lcccc}
\hline \multirow{2}{*}{ Variable } & \multicolumn{2}{c}{ Husband } & \multicolumn{2}{c}{ Wife } \\
intercept & 3.377 & 0.085 & 3.082 & 0.091 \\
$\log ($ age/17) & -0.044 & 0.189 & 0.598 & 0.182 \\
$\log ($ age/17) squared & 0.490 & 0.116 & 0.087 & 0.124 \\
Education level 1 & -0.336 & 0.052 & -0.232 & 0.068 \\
Education level 2 & -0.335 & 0.042 & -0.210 & 0.062 \\
Education level 3 & -0.262 & 0.038 & -0.189 & 0.060 \\
Education level 4 & -0.116 & 0.043 & -0.068 & 0.064 \\
Technical & 0.030 & 0.023 & 0.054 & 0.044 \\
Econ./adm. & 0.059 & 0.025 & 0.027 & 0.027 \\
General & 0.069 & 0.031 & 0.068 & 0.027
\end{tabular}


Table A2: ML Estimates of the Wage equations (ctd.)

\begin{tabular}{|c|c|c|c|c|}
\hline \multirow[b]{2}{*}{ Variable } & \multicolumn{2}{|c|}{ Husband } & \multicolumn{2}{|c|}{ Wife } \\
\hline & estimate & std. err. & estimate & std. err. \\
\hline 1990 & -0.111 & 0.043 & -0.118 & 0.047 \\
\hline 1991 & -0.063 & 0.042 & -0.097 & 0.049 \\
\hline 1992 & -0.018 & 0.043 & -0.063 & 0.048 \\
\hline 1993 & 0.003 & 0.043 & -0.070 & 0.049 \\
\hline 1994 & -0.065 & 0.042 & -0.080 & 0.046 \\
\hline 1995 & -0.071 & 0.044 & -0.117 & 0.047 \\
\hline 1996 & -0.070 & 0.041 & -0.081 & 0.044 \\
\hline 1997 & -0.071 & 0.042 & -0.092 & 0.046 \\
\hline 1998 & -0.061 & 0.043 & -0.079 & 0.046 \\
\hline 1999 & -0.029 & 0.044 & -0.026 & 0.047 \\
\hline 2000 & -0.011 & 0.042 & -0.029 & 0.049 \\
\hline$\tau_{m}$ & 0.491 & 0.004 & - & - \\
\hline$\tau_{f}$ & - & - & 0.572 & 0.008 \\
\hline
\end{tabular}




\section{References}

Apps, P. and R. Rees (1988), Taxation and the household, Journal of Public Economics, Vol. 35, pp. 355-369.

Bargain, O. and N. Moreau (2003), Is the collective model of labor supply useful for tax policy analysis? A simulation exercise. CESifo Working Paper No. 1052.

Beninger, D. and F. Laisney (2002), Comparison between Unitary and Collective Models of Household Labor Supply with Taxation, working paper.

Bloemen, H.G. (2008), Job Search, Hours Restrictions, and Desired Hours of Work, Journal of Labor Economics, Vol. 26, No. 1, pp. 137-179.

Bloemen, H.G. (2009), Am Empirical Model of Collective Household Labour Supply with Nonparticipation, Economic Journal, forthcoming.

Bloemen, H.G, and A. Kapteyn (2008), The Estimation of Utility Consistent Labor Supply Models by means of Simulated Scores, Journal of Applied Econometrics, Vol. 23, pp. 395-422.

Blundell, R, P.A. Chiappori, T. Magnac and C. Meghir (2007), Collective labor supply: heterogeneity and nonparticipation, Review of Economic Studies, Vol. 74, No. 2, pp. 417-445.

Blundell, R, A. Duncan, J. McCrae and C. Meghir (1999), Evaluating inwork benefit reform: the working families tax credit in the UK, mimeo, London, Institute for Fiscal Studies.

Blundell, R, and T. MaCurdy (1999), Labor supply: a review of alternative approaches, in: O. Ashenfelter and D. Card (eds.), Handbook of Labor Economics, Vol. 3, pp. 1559-1695.

Bosch, N. and B. van der Klaauw (2009), Analyzing female labor supply: evidence from a Dutch tax reform. IZA DP No. 4238. 
Chiappori, P.A. (1988), Rational Household Labor Supply, Econometrica, Vol. 56, pp. 63-89.

Chiappori, P.A. (1992), Collective Labor Supply and Welfare, Journal of Political Economy, Vol. 100, pp. 437-467.

Chiappori, P.A. (1997), Introducing Household Production in Collective Models of Labor Supply, Journal of Political Economy, Vol. 105, No. 1, pp. 191-209.

Chiappori, P.A, R. Blundell and C. Meghir (2005), Collective Labor Supply with Children, Journal of Political Economy, Vol. 113, No. 6, pp. 12771306.

Chiappori, P.A, B. Fortin and G. Lacroix (2002), Marriage Market, Divorce Legislation, and Household Labor Supply, Journal of Political Economy, Vol. 110, no. 11, pp. 37-72.

Donni, O. (2003), Collective Household Labor Supply: Nonparticipation and Income Taxation, Journal of Public Economics, Vol. 87, pp. 1179-1198.

Fortin, B. and G. Lacroix (1997), A test of the Unitary and Collective Models of Household Labor Supply, Economic Journal, Vol. 107, pp. 933-955.

Hausman, J. and P. Ruud (1984), Family labor supply with taxes, American Economic Review, Vol. 74, pp. 242-248.

Hoynes, H. (1996), Welfare transfers in two-parent families: labor supply and welfare participation under ADDC-UP, Econometrica, Vol. 64. pp. 295-332.

Keane, M, and R. Moffit (1998), A structural model of multiple welfare program participation and labor supply, International Economic Review, Vol. 39, No. 3, pp. 553-589.

Manser, M. and M. Brown (1980), Marriage and household decision-making: a bargaining analysis, International Economic Review, Vol. 1, No. 6, pp. $31-44$. 
McElroy, M.B. and M.J Horney (1981), Nash-bargained household decisions: towards a generalization of the theory of demand, International Economic Review, Vol. 22, No. 2, pp. 333-349.

Van Soest, A.H.O. (1995), Structural Models of Family Labor Supply: A Discrete Choice Approach, Journal of Human Resources, Vol. 30, No. 1, pp. 63-88.

Van Soest, A.H.O. and M. Das (2001), Family Labor Supply and Proposed Tax Reforms in the Netherlands, De Economist, Vol. 149, No. 2, pp. $191-218$.

Van Soest, A., I. Woittiez and A. Kapteyn (1990), Labor supply, income taxes and hours restrictions in the Netherlands, Journal of Human Resources 25, pp. 517-558.

Vermeulen, F. (2006), A Collective Model for Female Labour Supply with Nonparticipation and Taxation, Journal of Population Economics, Vol. 19, pp. 99-118.

Vermeulen, F., O. Bargain, M. Beblo, D. Beninger, R. Blundell, R. Carrasco, M. Chiuri, F. Laisney, V. Lachene, N. Moreau, M. Myck, and J. RuizCastillo (2006), Collective models of labor supply with nonconvex budget sets and nonparticipation: A calibration approach, Review of Economics of the Household, Vol. 4, pp. 113-127. 